\title{
The Kasterlee Formation and its relation with the Diest and Mol Formations in the Belgian Campine
}

Nö̈l VANDENBERGHE ${ }^{1, *}$, Laurent WOUTERS ${ }^{2}$, Marco SCHILTZ ${ }^{3}$, Koen BEERTEN ${ }^{4}$, IsaAc BerWOUTS 5 , Koen VOS ${ }^{5}$, Rik HOUTHUYS ${ }^{6}$, Jef DECKERS ${ }^{7}$, STEPHEN LOUWYE ${ }^{8}$, PIET LAGA ${ }^{9}$, JASPER VERHAEGEN $^{10}$, RIEKo ADRIAENS $^{11}$, MichIEL DUSAR ${ }^{9}$.

${ }^{1}$ Dept. Earth and Environmental Sciences, KU Leuven, Belgium; noel.vandenberghe@kuleuven.be.

${ }^{2}$ ONDRAF/NIRAS, Brussels, Belgium; l.wouters@nirond.be.

${ }_{3}^{3}$ Samsuffit, Boechout, Belgium; marco@samsuffit.be.

${ }^{4}$ SCK, Mol, Belgium; koen.beerten@sckcen.be.

${ }^{5}$ Sibelco,Belgium; Isaac.Berwouts@sibelco.com; koen.vos@sibelco.com.

${ }^{6}$ Consultant,Belgium; rik.houthuys@telenet.be.

${ }^{7}$ VITO,Mol,Belgium; jef.deckers@vito.be.

${ }^{8}$ Geology,UGent, Belgium; stephen.louwye@ugent.be.

${ }^{9}$ Geological Survey of Belgium, Brussels, Belgium; piet.laga@skynet.be; mdusar@naturalsciences.be.

${ }^{10}$ VPO, Planning Bureau for the Environment and Spatial Development, Department of Environment, Flemish Government, Koning Albert II-laan 20, 1000 Brussels, Belgium; jasper.verhaegen@vlaanderen.be.

${ }^{11}$ Qmineral, Heverlee-Leuven, Belgium; radriaens@qmineral.com.

* corresponding author.

ABSTRACT. Stratigraphic analysis of cored and geophysically logged boreholes in the Kasterlee-Geel-Retie-Mol-Dessel area of the Belgian Campine has established the presence of two lithostratigraphic units between the classical Diest and Mol Formations, geometrically related to the type Kasterlee Sand occurring west of the Kasterlee village and the study area. A lower 'clayey Kasterlee' unit, equivalent to the lithology occurring at the top of the Beerzel and Heist-op-den-Berg hills, systematically occurs to the east of the Kasterlee village. An overlying unit has a pale colour making it lithostratigraphically comparable to Mol Sand although its fine grain size, traces of glauconite and geometrical position have traditionally led stratigraphers to consider it as a lateral variety of the type Kasterlee Sand; it has been named the 'lower Mol' or 'Kasterlee-sensu-Gulinck' unit in this study. In the present analysis, the greenish glauconitic Kasterlee Sand in its hilly stratotype area evolves eastwards into the lower 'clayey Kasterlee' unit and possibly also into an overlying 'lower Mol' or 'Kasterlee-sensu-Gulinck' unit, although it is equally possible that the latter unit has an erosive contact and therefore is stratigraphically slightly younger than the type Kasterlee Sand west of the Kasterlee village. A lateral extension of this detailed stratigraphic succession into the faulted zone of east Limburg is proposed.

KEYWORDS: Neogene, dinoflagellate cyst stratigraphy, clayey Kasterlee, lower Mol, Kasterlee-sensu-Gulinck.

\section{Introduction}

This paper deals with the Kasterlee Formation in the Belgian Campine area (Antwerp and Limburg) and the transition from the Kasterlee Formation to the underlying Diest Formation and the overlying Mol Formation. Like many lithostratigraphic units in Belgium also the Kasterlee Formation has a stratigraphic precursor name 'Casterlien', already introduced in 1882 by Dumont. Its position with respect to over- and underlying strata has been a subject of debate in the stratigraphic literature (Tavernier, 1954; Laga \& Louwye, 2006). The definition of the Kasterlee Formation presently described in the lithostratigraphy inventory of the National Commission for Stratigraphy Belgium (NCS) (https://ncs.naturalsciences.be/paleogene-neogene/25-kasterleeformation-kl), follows the lithostratigraphy review by Laga et al. (2001) which is honouring the principles and the discussions about this unit by earlier authors such as Gulinck (1963, p. 33). The stratotype of the Kasterlee Formation is the hilly area on the right bank of the Kleine Nete valley ending in the east at the village of Kasterlee (the Lichtaart-Kasterlee hill ridge on Fig. 1). According to Laga et al. (2001) the Kasterlee Formation consists of grey micaceous sand without fossils, slightly glauconiferous with lenses of micaceous clay and micaceous fine sand at the base, often very glauconitic, burrowed and mottled. This description however is general and hardly allows a clear distinction from other lithostratigraphic units or parts of units. Noteworthy is that neither Gulinck (1963, p. 33) nor Laga et al. (2001) include the colour of the sands as a discriminatory parameter in the identification. The Kasterlee Formation as identified in borehole descriptions in the Archives of the Geological Survey of Belgium is often described as 'grey' or 'grey-greenish', certainly depending on the amount of glauconite which apparently is very variable. In a dense series of reconnaissance boreholes between Herentals and the area south of Geel, Halet (1935) described the 'Casterlien (D2 of the author)' overlying the Diest Sand, as grey to grey-greenish with at the top pale grey sand, even with a lignitic horizon-claimed however to be of end last interglacial by Gullentops \& Huyghebaert (1999, p. 192) - and including $\mathrm{cm}$ thick layers of violet and salmon coloured plastic clay. Hence it is not surprising that also Laga et al.
(2001) report in their description that the Kasterlee Formation is often hardly distinguishable from the underlying Diest Formation as well as from the overlying Mol Formation. Clay lenses are reported from both the base of the Kasterlee Formation and from the top of the Diest Formation (see e.g. in boreholes Fig. $1 \mathrm{nr} 22-$ Postel 018E0097, Fig. 1 nr 1- Belchim 031W0221, Fig. 1 nr 23Overpelt 032E0128). In addition, in many borehole descriptions in the Archives of the Geological Survey of Belgium it is reported that in its lower part the Mol Formation is slightly glauconiferous (Laga et al., 2001), informally described as 'Mol Inférieur'.

The problem of ranking a specific interval either as $\mathrm{Mol}$ or Kasterlee Sand was recognized in the Belchim (Eurochimic) borehole (Fig. $1 \mathrm{nr}$ 1- 031W0221) in Mol-Dessel by Gulinck (1963, p. 32 discussing the Mol Sand); this last author finally chose to interpret that specific interval in the Belchim borehole between $14.5 \mathrm{~m}$ and $32.5 \mathrm{~m}$ as Kasterlee Sand (Gulinck et al., 1963 ) and this interpretation as Kasterlee Sand was consistently applied by Gulinck and collaborators in the Archives of the Geological Survey of Belgium to similar lithological intervals in later borehole descriptions from the area east of Kasterlee. The practical criterion to identify the top of this 'Kasterlee Sandsensu-Gulinck' in boreholes has been the appearance of a green colour in the drilling mud. The origin of this green colour must be the decomposition of some sparse glauconite grains by the drilling operation or the presence of light green coloured clay in the sand itself, leaving a subtle green shine on core samples (see also further comments e.g. in the ON-Dessel-2 (kb17d31W-B299) (Fig. 1 nr 9- and RUS boreholes (RUS04/03) (Fig. 1 nr 34) interpretations below)). The practice of identifying the Kasterlee Sand unit as done by Gulinck was also respected in the 1:50 000 Mol geological map sheet 17. In support of this view, Gullentops \& Vandenberghe $(1995$ b, p. 15) report that the garnet content in the interval concerned in the Belchim borehole is similar to the content in the Kasterlee Formation of the type area whilst the Mol sand heavy minerals in the Belchim borehole are dominated by tourmaline and parametamorphic minerals. Note also that in the Belchim borehole the interval with clay lenses occurring between the sands in the interval $33 \mathrm{~m}$ to $35 \mathrm{~m}$ is attributed to the top of the Diest Sand by Gulinck et al. (1963, p. 284). 


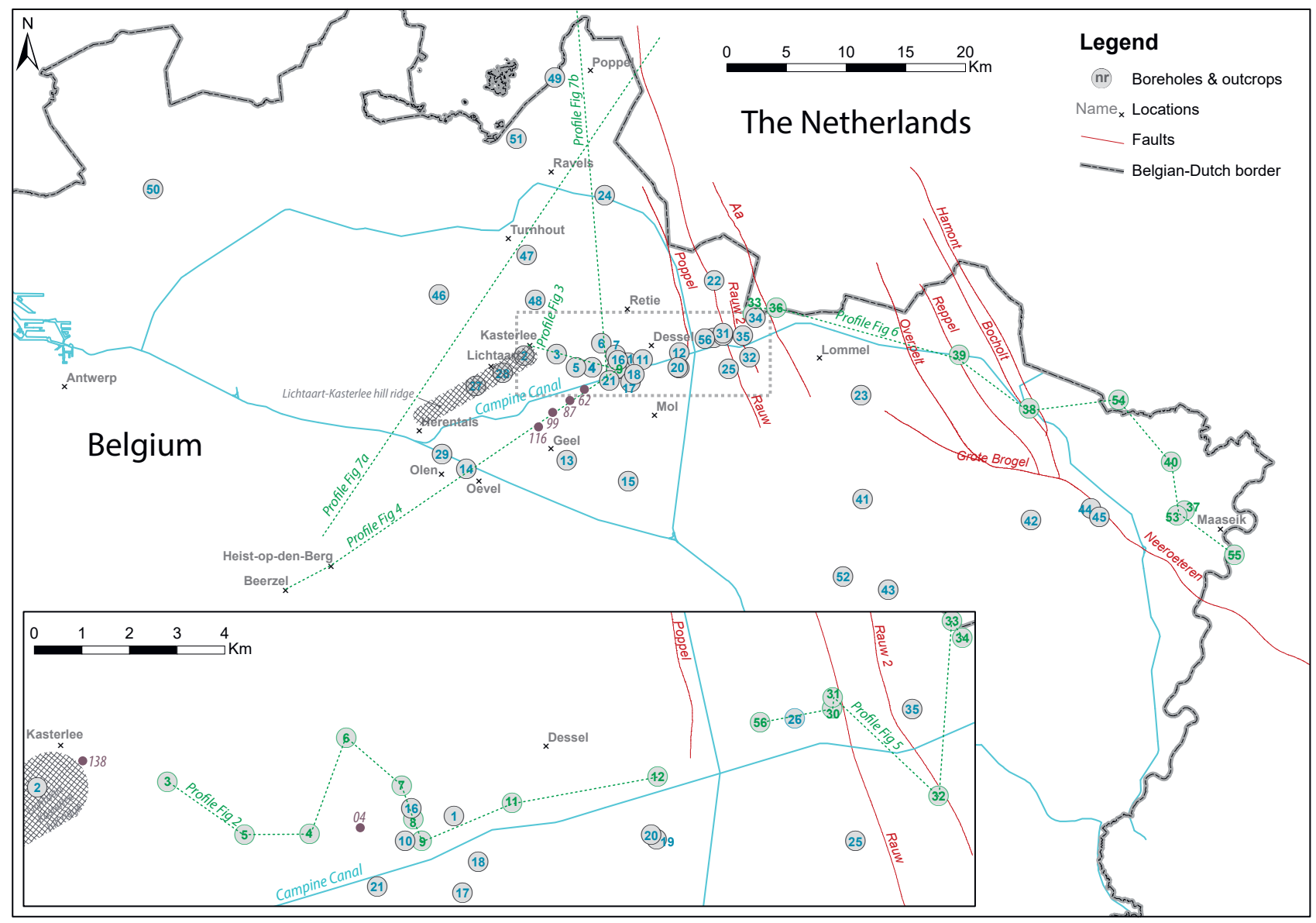

Figure 1. General location map of the numbered borehole and outcrop positions discussed in the text. The position of the profiles in Figs 2, 3, 4, 5, 7a $\& b$ is represented by dashed lines. The stippled rectangle is magnified in the bottom of the map. The main canals are indicated by blue lines and the administrative centre of municipalities is indicated by x. The fault pattern in red lines is from Deckers et al. (2019).

Table 1. The numbers in Figure 1 are linked to the common name of each borehole or outcrop with their corresponding Geological Survey of Belgium (GSB) and Flemish government (DOV) reference codes (DOV, 2020). The order of the numbering follows the order of their first appearance in the text. The link to the borehole or outcrop data can be found in the NCS Neogene Reference Set (see De Nil et al., 2020, this volume).

\begin{tabular}{|c|c|c|c|c|c|c|c|}
\hline Name & Code GSB & Code DOV & $\mathrm{Nr}$ & Name & Code GSB & Code DOV & $\mathrm{Nr}$ \\
\hline Belchim & 031W0221 & kb17d31w-B212 & 1 & Olen Sluice & 045W0253 & GRAN-BGD045W0253 & 29 \\
\hline N19g Kasterlee & & TO-20120101 & 2 & ZEHO8/05 & & ZEH08/05 & 30 \\
\hline ON-Kasterlee 1 & 030Е0335 & ON-Kasterlee 1 & 3 & ON-Mol-2B & 031E0440 & ON-Mol-2B & 31 \\
\hline ON-Retie 2 & 031W0375 & ON-Retie 2 & 4 & MHL 03/01 & 032W0460 & GEO-03/071-B2 & 32 \\
\hline ON-Geel 1 & 031W0357 & ON-Geel 1 & 5 & SCK13 /Postel 2 & 032W0415 & kb17d32w-B385 & 33 \\
\hline ON-Retie 1 & 031W0362 & ON-Retie 1 & 6 & RUS04/03 & & RUS04/03 & 34 \\
\hline ON-Dessel 3 & 031W0354 & ON-Dessel 3 & 7 & Lommel (Russendorp) & 031E0341 & kb17d31e-B323 & 35 \\
\hline ON-Dessel 4 & 031W0353 / 031 W0376 & ON-Dessel 4 & 8 & Lommel 2 & 032W0409 & kb17d32w-B379 & 36 \\
\hline ON-Dessel 2 & 031W0338 & kb17d31w-B299 & 9 & Maaseik & 049W0220 & kb18d49w-B220 & 37 \\
\hline ON-Dessel 5 & 031W0370 & ON-Dessel 5 & 10 & Bocholt & 033W0153 & B/7-0356 & 38 \\
\hline Donk Sand pit & & SIB-DON-02-03 & 11 & St. Huibrechts-Lille & 033W0139 & kb18d33w-B142 & 39 \\
\hline Pinken Sand pit & & SIB-PIN-03-03 & 12 & Kinrooi & $049 W 0230$ & kb18d49w-B230 & 40 \\
\hline Geel & 046W0388 & $\mathrm{B} / 1-1100$ & 13 & Hechtel & 047E0192 & kb17d47e-B186 & 41 \\
\hline Olen & $045 E 0476$ & B/1-1101a & 14 & Wijshagen & $048 W 0180$ & kb18d48w-B181 & 42 \\
\hline Meerhout & 046W0389 & B/1-1117a & 15 & Helchteren & 062E0261 & kb25d62e-B265 & 43 \\
\hline ON-Dessel 1 & 031W0300 & ON-Dessel 1 & 16 & Opitter Molen sand pit & 048E0151C & BGD048E0151C & 44 \\
\hline ON-Mol 1 & $031 W 0314$ & ON-Mol 1 & 17 & Opitter Solterheide sand pit & 048E0296 & BGD048E0296 & 45 \\
\hline VITO-KWO & & B/1-96240 & 18 & Gierle & 017W0158 & kb8d17w-B14 & 46 \\
\hline Pidpa & 031E0418 & BGD031E0418 & 19 & Oud Turnhout & 017E0401 & kb8d17e-B497 & 47 \\
\hline Pidpa WVP8 & $031 \mathrm{E} 0435$ & B/1-96196 & 20 & Rees & 017E0399 & kb8d17e-B495 & 48 \\
\hline SCK 15 & $031 W 0237$ & B/1-0158 & 21 & Weelde & 008E0133 & kb8d8e-B26 & 49 \\
\hline Postel & 018 E0097 & kb9d18e-B30 & 22 & Wuustwezel & 015E0298A & BGD015E0298A & 50 \\
\hline Overpelt & 032E0128 & kb17d32e-B107 & 23 & Weelde SCK Vlieghaven & 008E0159 & kb8d8e-B161 & 51 \\
\hline Arendonk & 018W0197 & kb9d18w-B81 & 24 & Helchteren outcrop & & TO-19950101B & 52 \\
\hline Mol-Rauw & 031E0287 & kb17d31e-B279 & 25 & Maaseik Jagersborg & $049 W 0236$ & kb18d49w-B235 & 53 \\
\hline Mol-Sas & 031E0288 & kb17d31e-B280 & 26 & Stramproy & $N L$ & В57H0058 & 54 \\
\hline Lichtaart sand pit Hoge Berg & & TO-19990101B & 27 & Roosteren & $N L$ & B60A0325 & 55 \\
\hline Hukkelberg sand pit & & TO-19630101 & 28 & Den Diel & 031E0337 & kb17d31e-B319 & 56 \\
\hline
\end{tabular}


The problem of the identification criteria of the Kasterlee Sand with respect to the definition of a boundary between the Kasterlee and Diest Sand units was recently raised again when new good quality data became available in a series of cored and geophysically logged ONDRAF-NIRAS boreholes accompanied by numerous geomechanical Cone Penetration Tests (CPT) between Kasterlee, Geel, Retie, Mol and Dessel (Wouters \& Schiltz, 2012; Louwye et al., 2007) and also with the interpretation of well-documented reconnaissance drillings by Vos (2009) in the area Postel-Lommel. The present study discusses the information from these new data and attempts to integrate the stratigraphic results with the classical interpretations of the Kasterlee Formation in the Antwerp and Limburg Campine area (Laga et al., 2001).

In the present paper we use the terminology Formation and Member, or Sand with capital S, only if the concerned interval can be identified as reported in the lithostratigraphic nomenclature (National Commission for Stratigraphy Belgium, 2020). In all other cases we will use the neutral term 'unit' and when introducing in such cases informal names, we will put these names between 'quotes'.

The locations of the numbered boreholes and discussed outcrop sections are given in Figure 1 together with their GSB (Geological Survey of Belgium) and DOV (Databank Ondergrond Vlaanderen) codes and number in Table 1; in the text the number and the common names of the boreholes and sections are used and when the borehole is mentioned for the first time, it is followed between brackets by its GSB or DOV Code as given in the table. The access to particular borehole data is discussed in De Nil et al. (2020, this volume).

\section{From the Kasterlee Formation type area to the Kasterlee-Geel-Retie-Mol-Dessel area based on new data from ON-cored boreholes in the Kasterlee-Geel- Retie-Dessel area}

\subsection{The Kasterlee Formation at Kasterlee village}

In the hill on the right bank of the Kleine Nete valley, the stratotype area of the Kasterlee Formation (Laga et al., 2001, p. 145), no Mol Sand occurs and the Kasterlee Sand is separated from the overlying very similar Poederlee Sand by the presence of the Hukkelberg Gravel at the base of the Poederlee Sand; this gravel consists of very typical small flattened white quartz pebbles as described from the Lichtaart (Groeve Lichtaart) (TO19990101B) (Fig. $1 \mathrm{nr} 27$ ) and Hukkelberg (Groeve Hukkelberg) (TO-19630101) (Fig. $1 \mathrm{nr}$ 28) sand pits (de Heinzelin, 1963, p. 216-217; Gulinck, 1960). The Kasterlee Sand in the type area is described as fine glauconiferous sand; Gullentops (1963) reports in the Lichtaart outcrop a maximum of $5 \%$ glauconite and also Adriaens (2015, p. 179) reports almost 5\% glauconite near Hukkelberg. The succession of Kasterlee Sand and the overlying Hukkelberg Gravel and Poederlee Sand, was exposed at the most eastward end of the hill ridge during the $\mathrm{N} 19 \mathrm{~g}$ ring road works in 2012 southwest of the Kasterlee village centre (TO-20120101) (Fig. 1 nr 2;Plate 1B). In this section Adriaens (2015, p. 181) reports $2 \%$ glauconite pellets in the top $2 \mathrm{~m}$ of the Kasterlee Sand and up to $6 \%$ below.

Although in many borehole descriptions in the stratotype area in the absence of a base gravel the boundary of the finer Kasterlee Sand with the underlying coarser Diest Formation is not well defined, Halet (1935) recognized a clear boundary between Kasterlee and Diest Sand in regional profiles between Herentals, Olen, Geel and Kasterlee. Furthermore Gulinck (1963) and Tavernier \& de Heinzelin (1963) published a geological map with a fairly straight boundary between 'Casterlien' and 'Diestien typique' based on the general distinction between coarser glauconite-rich Diest Sand and finer-grained Kasterlee Sand. In their comment on this map, Tavernier \& de Heinzelin (op.cit., p. 15) described the Kasterlee Sand with its clay lenses as a sublittoral facies installed at the end of the Diest Sand transgression.

East of Kasterlee, 10 cored boreholes of $50 \mathrm{~m}$ deep and many additional geotechnical soundings (CPT) were commissioned by ONDRAF/NIRAS (ON) in the Kasterlee-Geel-Retie-Mol-Dessel area to unravel the lithological geometries and transitions from the surface until into undisputed Diest Formation (Wouters \& Schiltz, 2012). The boreholes have natural gamma radioactivity (GR) and resistivity (RES) logs; grain-size analyses, glauconite content and air permeability determinations have been made for hydrogeological purposes. All CPT soundings have, in addition to the directly measured cone resistance and friction ratio logs, also continuous calculated permeability (hydraulic conductivity) parameter logs (Robertson, 2010; Schiltz, 2011; Rogiers et al., 2012, 2014a \& b). Because of the common occurrence of apparently transitional intervals, the visual inspection of the cores (colour, lithology, sedimentary structures) and of the analytical data did not allow a straightforward interpretation of the exact position of the boundaries between the Diest, Kasterlee and Mol Formations, which are the lithostratigraphic units expected in the area based on the geological maps and the stratigraphic data of the NCS. In addition the colour of the sediments was not a reliable criterion because of its change with time and drying degree (see e.g. Plate $1 \mathrm{~A}, \mathrm{G}$ ), because of the processing influence on colour in the photographs and also because the original colour of the drilling mud is unknown. The stratigraphic analysis described below and shown in Figure 2 is based on criteria allowing a robust correlation between the boreholes and selected in line with the traditional main lithological characteristics of the Mol, Kasterlee and Diest Formations in the area. The main criteria that appear consistent for correlation (Fig. 2) are a combination of visual inspection of the core lithology, dominant sediment colour away from transition zones, natural gamma ray $\log (\mathrm{GR})$, grainsize data (in ON-boreholes: 1 sample/2 $\mathrm{m}$ interval), occurrence of gravel, glauconite pellet content, mineralogical analyses and sedimentary structures. The criteria applied to the different boreholes represented and correlated in Figure 2 are discussed below.

In all boreholes Quaternary deposits occur near the surface and have a limited thickness. In the cores they appear as loamy sand, sometimes laminated, with various amounts of organic matter and overall they are heterogeneous with respect to the underlying Mol Formation. The observed thickness differences of the Quaternary deposits (Fig. 2) are expected as the present landscape is the result of alternating phases of erosion and accumulation (Beerten et al., 2014)

\subsection{The position of the stratotype Kasterlee Formation in the ON-Kasterlee-1 borehole stratigraphy}

The ON-Kasterlee-1 borehole (Fig. 1 nr 3- 030E0335; Fig. 2) is situated about $2 \mathrm{~km}$ to the east of the Kasterlee village. Towards the east, the hill with the type Kasterlee Sand ends just west of the topographically already lower lying village. The position of the top of the Kasterlee Sand in the hill ridge is well defined by the general occurrence of the Hukkelberg Gravel level at the base of the overlying Poederlee Sand as discussed above. The ground level at the ON-Kasterlee- 1 borehole is only about 1 to $2 \mathrm{~m}$ above the Hukkelberg Gravel in the 2012 N19g road works excavation that at the same time is the most eastern occurrence of the Hukkelberg Gravel. In the about $2 \mathrm{~km}$ distance between the end of the hill ridge at the N19g road works site and the ONKasterlee-1 borehole also six $30 \mathrm{~m}$-deep cone penetration test (CPT) soundings are available (Schiltz, 2011).

The stratigraphic interpretation of the ON-Kasterlee-1 borehole data and its correlation with the other ONDRAF/NIRAS boreholes in the area discussed below (Fig. 2), is mainly based on the evolution of the GR $\log$, the presence of a $>500 \mu \mathrm{m}$ grain-size fraction, the clay fraction or $<62 \mu \mathrm{m}$ fraction and the glauconite pellet content. Resistivity logs in the present work show more variability and are therefore less straightforward for correlation purposes and not represented on Figure 2.

The upper sand below the base of the Quaternary until $12-13 \mathrm{~m}$ depth is white to grey contrasting with the clay-enriched glauconite bearing green sand below (Plate 1F). Therefore the marked GR increase level at $12.5 \mathrm{~m}$ is interpreted as the top of a 'clayey Kasterlee' unit (level 1 in Fig. 2) and the grey to white sand above is interpreted as a 'lower Mol' unit. The 1 to $2 \mathrm{~m}$ greenish shining sand at the base of the 'lower Mol' unit, lacking pelletal glauconite grains, is interpreted as reworked sand from the underlying 'clayey Kasterlee' unit. Arguments for the reworking of this thin interval are the lamination (Plate 1F) which 


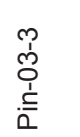
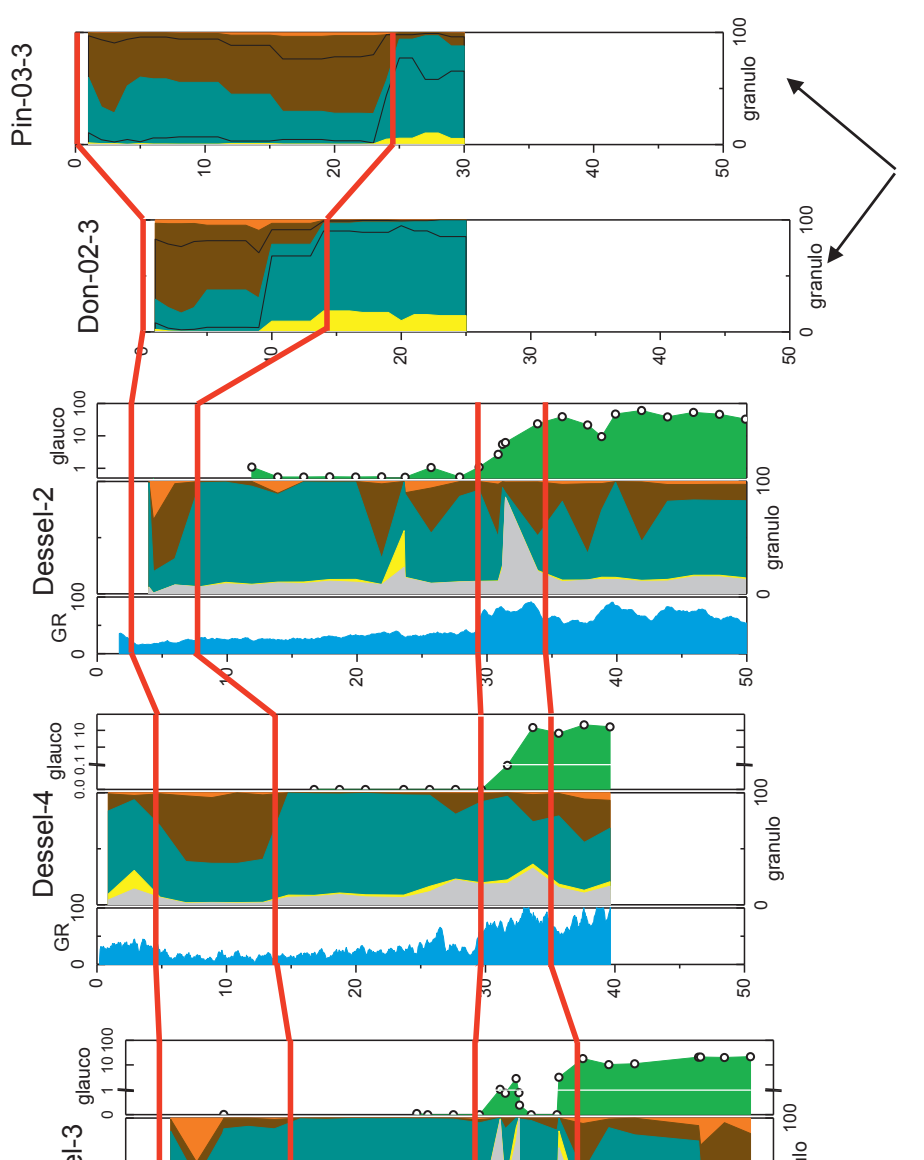

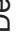

땅

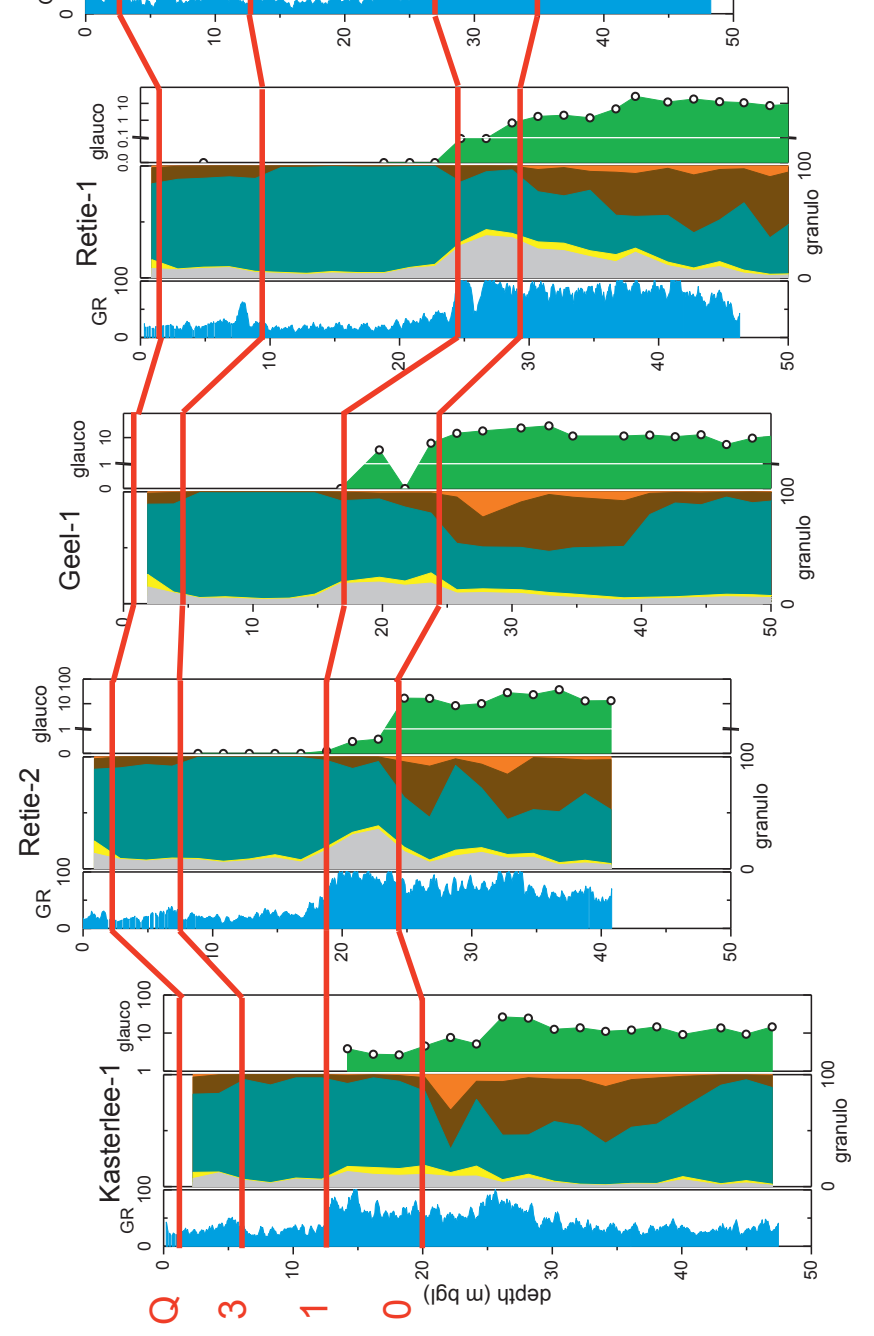

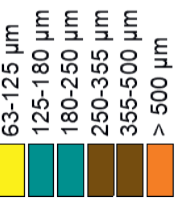

울혈

氜

光

के $2 \frac{\pi}{0} \frac{0}{2}$

过㟧屒

웅고용

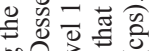

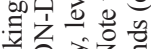

国需

毛过志㤩

娄荡

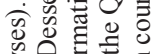

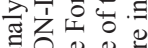

\%

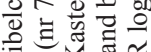

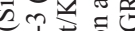

을 总.

छั

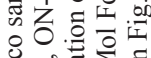

60

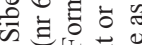

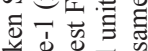

音氙完号

茫羊可

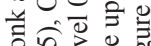

行已政

o

宁 $\Xi$

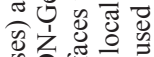

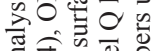

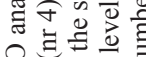

$\Leftrightarrow$, of

ट

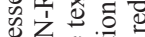

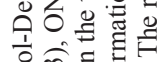

응

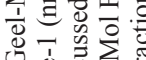

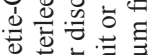

垃㟥

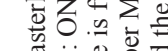

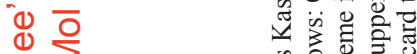

$\sum$

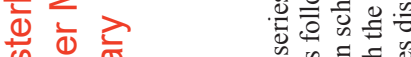

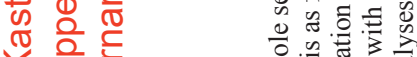

ह்

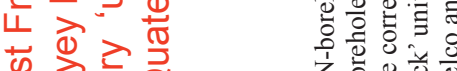

ब ब

प0 0 (1)

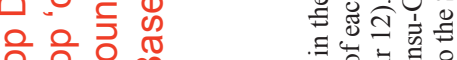

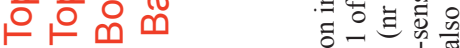

$\ddot{\circ} \ddot{\dot{m} \dot{O}}$

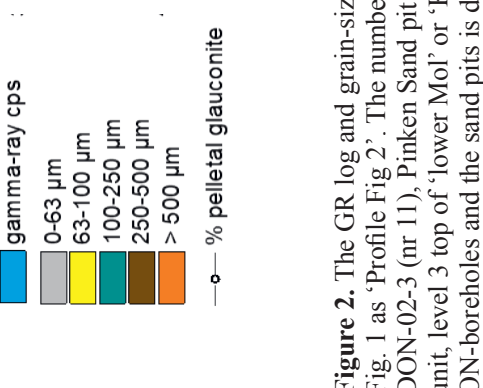


is uncommon in either the classical Mol or Kasterlee Formations and the lack of bioturbations commonly present in the undisturbed type Kasterlee Formation. A boundary can be interpreted at about $5.4 \mathrm{~m}$ between slightly coarser sand above containing a significant grain-size fraction larger than $250 \mu \mathrm{m}$, and slightly finer sand below without this fraction; as this boundary is consistently found in the other boreholes of the ONDRAF/NIRAS series we call this subdivision tentatively a division between 'lower Mol' and 'upper Mol' units (level 3 in Fig. 2).

The upper metres of the green 'clayey Kasterlee' unit have a marked high GR signal and analyses show 3-4\% glauconite and up to $20 \%$ fraction smaller than $100 \mu \mathrm{m}$. The unit continues below this clayey upper interval and is followed below by the Diest Sand. The Diest Formation has a substantial part $>250 \mu \mathrm{m}$ with also a $>500 \mu \mathrm{m}$ grain-size fraction that is almost absent in the 'clayey Kasterlee' unit. Furthermore, it contains about $10 \%$ more glauconite pellets than the 'clayey Kasterlee' unit, although no unique level marking this lithological difference is visually observed in the cores. A practical robust level that can be correlated between the different boreholes appears to be the depth below which the sediment picks up a $>500 \mu \mathrm{m}$ size fraction. This level occurs around $20 \mathrm{~m}$ deep and is used in Figure 2 (level 0 ) to mark the boundary between the Diest Sand and the 'clayey Kasterlee' unit of the Kasterlee Formation. The CPT analyses also show a marked signal at this boundary which is defined by the appearance of $>500 \mu \mathrm{m}$ grains (Schiltz, 2011). With this definition of the top Diest Formation underlying the Kasterlee Formation we closely honour the profile PL.VII by Halet (1935). This author shows under the Lichtaart-Kasterlee hill about $15 \mathrm{~m}$ thick Kasterlee Sand (D2 of this author) with the base at a topographic level of about -3 m TAW (Tweede Algemene Waterpassing) while the base of the 'clayey Kasterlee' unit, a part of the Kasterlee Formation in the ON-Kasterlee-1 borehole, is located at $-3.2 \mathrm{~m}$ TAW. Halet (1935) also reported a slightly coarser level at the base of the Kasterlee Sand in its type area considering it as a reworking of the underlying Diest Sand which according to this author contains several such coarser grain intervals, an observation confirmed in the $\mathrm{ON}$ borehole cores. Based on the grain-size data given in Gulinck et al. (1963), the clayey interval in the Belchim borehole between about 32.5 and $35.5 \mathrm{~m}$ ('lentilles d'argile violacée') belongs to the 'clayey Kasterlee' unit as the size fraction $>417 \mu \mathrm{m}$ only occurs below this interval. The search for a particularly coarse level to define the base of the Kasterlee Formation has also been the systematically applied practice in borehole descriptions by the Geological Survey of Belgium in the Campine by one of the present authors (P.L.). The top metres of the Diest Formation, defined with the appearance of a fraction $>500 \mu \mathrm{m}$ grains, still contains thin intervals with finer sediment resembling type Kasterlee Sand suggesting that the sedimentation environment in the Kasterlee Formation became already gradually installed by the end of the deposition of the Diest Formation. Vivianite concretions occur deeper than $21.15 \mathrm{~m}$. This phosphate mineral can only form in an environment with a high iron to calcium ratio, unlike marine waters of normal salinity and therefore must have a diagenetic origin.

This stratigraphic interpretation of the ON-Kasterlee-1 borehole leads to the conclusion that over less than $2 \mathrm{~km}$ distance about $10 \mathrm{~m}$ of green-grey Kasterlee Sand speckled with typical dark glauconite grain spots in the Kasterlee hill region is replaced laterally to the east by grey-white sands interpreted here as 'lower Mol' and overlying 'upper Mol' units. CPT measurements in between the ON-Kasterlee-1 borehole and the Lichtaart-Kasterlee hill allow to correlate the 'clayey Kasterlee' unit in the borehole with the lower part of the Kasterlee Formation section under the hill (Fig. 3). Together with the termination of the hill in Kasterlee, also ends the extension of the Poederlee Sand that is overlying the Kasterlee Formation on the hill.

\subsection{The ON-Retie-2 borehole stratigraphy}

As in the ON-Kasterlee-1, the sudden increase in GR at $19.15 \mathrm{~m}$ in the ON-Retie-2 borehole (Fig. $1 \mathrm{nr} 4)$ (031W0375) (Fig. 2) marks the top of the green 'clayey Kasterlee' unit (Plate 1I) and the overlying pale grey-white sand is interpreted as the 'lower Mol' unit. The boundary between an 'upper Mol' unit based on the occurrence of a $>250 \mu \mathrm{m}$ fraction is occurring at ca. 8 $\mathrm{m}$. The 'lower' and 'upper Mol' units in the section display a greenish-grey shine interpreted as inherited from the drilling mud containing finely dispersed decomposed glauconite (see Introduction). The lowermost about $2 \mathrm{~m}$ of the 'lower Mol' unit picks up a darker grey colour and within it at $18.8 \mathrm{~m}$ a clayey black, probably organic level is present; this basal $2 \mathrm{~m}$ interval is also characterised by slightly increased GR and RES values reflecting the higher clay content and the presence of organic matter. The upper part of the 'clayey Kasterlee' unit, till almost $22 \mathrm{~m}$ has several thin grey clay layers (Plate 1I), some with vivianite at their upper side, while its lower part is more homogeneous with thinner clay layers that can take a salmon colour. The 'clayey Kasterlee' unit is bioturbated. The base of the 'clayey Kasterlee' unit is situated at almost $24 \mathrm{~m}$ depth where the sediment becomes more sandy, brown coloured and picks up a $>500 \mu \mathrm{m}$ grain-size fraction, hence the Diest Formation. The sand fraction of the 'clayey Kasterlee' unit contains up to $10 \%$ glauconite pellets in contrast to their absence, except for some rare grains, in the overlying 'lower Mol' unit and the 30 to $60 \%$ glauconite pellets in the sand fraction of the Diest Formation below.

\subsection{The ON-Geel-1 borehole stratigraphy}

In the core description of the ON-Geel-1 (Fig. $1 \mathrm{nr} 5$ ) (031W0357) borehole, the boundary between pale sand and the green 'clayey Kasterlee' unit occurs at $16.8 \mathrm{~m}$ (level 1 in Fig. 2). The GR log is not available in this borehole but based on the appearance of glauconite pellets and the increase up to $20 \%$ in $<62 \mu \mathrm{m}$ size fraction, the level at $16.8 \mathrm{~m}$ is analogous to the increase in GR level in the other ON-boreholes in the area marking the top of the 'clayey Kasterlee' unit. This interpretation is also supported by the CPT signature at that level. Above this level the boundary between a 'lower Mol' and an 'upper Mol' unit occurs at about $5 \mathrm{~m}$ depth based on the presence of $\mathrm{a}>250 \mu \mathrm{m}$ coarse size fraction in the 'upper Mol' unit. The upper part of the 'clayey Kasterlee' unit contains grey clay layers and it becomes more homogeneous below $18.9 \mathrm{~m}$ and is gradually changing colour from green to brown. The appearance of $>500 \mu \mathrm{m}$ size grains at $24.5 \mathrm{~m}$ marks the top of the Diest Formation. The glauconite pellet content in the 'clayey Kasterlee' unit is $<10 \%$ while in the Diest Formation it is $>10 \%$ and up to $30 \%$.

\subsection{The ON-Retie-1 borehole stratigraphy}

In the ON-Retie-1 (Fig.1 nr 6) (031W0362) borehole the sudden increase to the high GR event occurs at $24.6 \mathrm{~m}$ (level 1 in Fig. 2) and corresponds in the cores to the transition from grey-white to green sand (Plate 1G). Therefore, as in the other ON-boreholes discussed, this level corresponds to the top of the 'clayey Kasterlee' unit. At the base of the overlying 'lower Mol' unit, a downwards GR increase and RES decrease occur in the lowermost $2 \mathrm{~m}$; as this gradient occurs in grey-white coloured sand, as observed in the cores, it has to be included in the 'lower Mol' unit and most probably is due to reworked material included at the base of this Mol Formation. A coarse interval with dispersed pebbles occurs at $8 \mathrm{~m}$ depth and a boundary with a slightly coarser sand containing a fraction $>250 \mu \mathrm{m}$ occurs at $10 \mathrm{~m}$ depth. Therefore, as observed in the other ON-boreholes in this area, an 'upper Mol' unit occurs above about $9 \mathrm{~m}$ depth (level 3 in Fig. 2).

The upper about 3-4 $\mathrm{m}$ of the cores in the 'clayey Kasterlee' unit is green, clayey and with clay laminae (Plate 1I). Some of the clay lenses have a salmon colour. Below $28 \mathrm{~m}$ the sediment becomes more homogeneous and the base of this unit is put at about $29.5 \mathrm{~m}$ (level 0 in Fig. 2) based on the appearance below this depth of a size fraction $>500 \mu \mathrm{m}$. The glauconite pellet content at the base of the 'clayey Kasterlee' unit is large, about 35\%, and decreases to only a few \% at its top. In the 'clayey Kasterlee' unit the modal grain size is about $180-190 \mu \mathrm{m}$ whilst in the top of the Diest Formation just below it is $>225-250 \mu \mathrm{m}$, consistent with the appearance of a coarse sand fraction in the Diest Formation. In the Diest Formation the size fraction $>250 \mu \mathrm{m}$, including a $>500 \mu \mathrm{m}$ fraction, increases downwards with modal size reaching $>330 \mu \mathrm{m}$, in particular deeper than about $36 \mathrm{~m}$. At this depth the pelletal glauconite content also increases up to $40-60 \%$ (Adriaens, 2015, fig. 117). 


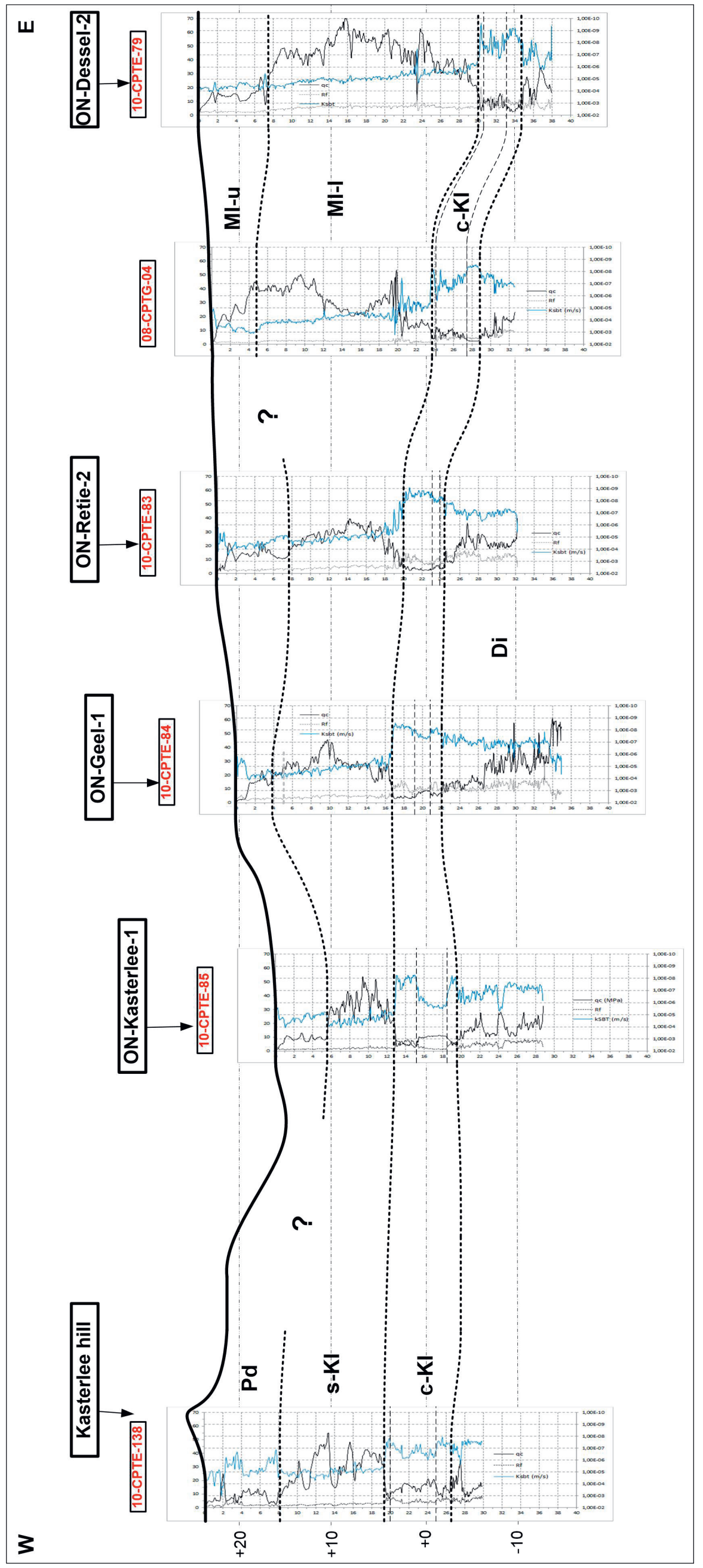

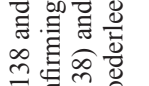

so 항 궝

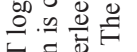

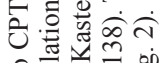

造

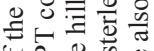

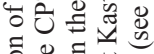

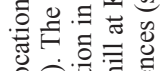

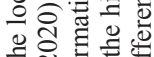

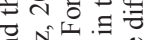

i

on

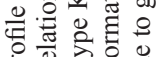

닌

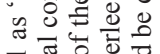

कis.

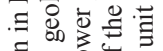

氞家岕

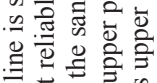

石

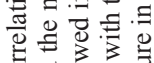

웡흐웜

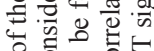

응 웡

款品

을 음

人.

进它究品

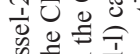

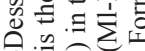

䔩品

응

․ㅗㅇ

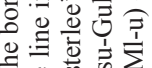

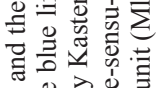

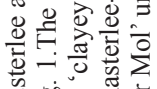

跑记

To

要 $\sum^{2}$

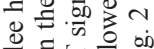

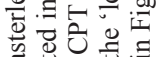

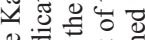

혀의

过

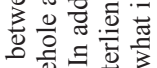

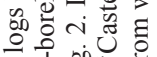

它完宝品

응

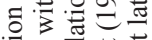

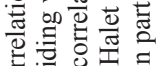

8 .

ल. 융 㝏

IIt 


\subsection{The ON-Dessel-3 borehole stratigraphy}

Increased GR values characterizing the 'clayey Kasterlee' unit as discussed above, occur in the ON-Dessel-3 (Fig.1 nr 7) (031W0354) borehole definitely below $28 \mathrm{~m}$ (Fig. 2). However there is already an increased GR signal and clay content between 26 and $28 \mathrm{~m}$; above $25.6 \mathrm{~m}$ the GR values are as low as usually in the 'lower Mol' unit. The colour of the sand changes at $25.6 \mathrm{~m}$ from grey-white above to greenish below. In the core an erosive contact is observed at $26.8 \mathrm{~m}$ and the green sand above this contact, between 25.6 and $26.8 \mathrm{~m}$, is laminated as can be expected from reworking and it lacks bioturbations which commonly occur in the Kasterlee Sand. Therefore, notwithstanding its greenish colour, the $1.2 \mathrm{~m}$ above the erosive level is considered as reworked sand from the underlying Kasterlee Formation. This interpretation is supported by the sudden change in relative proportions of the clay fraction minerals (Adriaens, 2015, p. 146) at the erosive contact at $26.8 \mathrm{~m}$ which is consequently considered as the base of the 'lower Mol' unit. In the grey-white sand above, three gravel levels occur closely spaced to each other between 12 and $13.6 \mathrm{~m}$. The lower one corresponds to the change between a slightly coarser 'upper Mol' unit with modal size up to about 200 $\mu \mathrm{m}$ and containing a significant fraction coarser than $250 \mu \mathrm{m}$, and a slightly finer 'lower Mol' unit with modal size close to 170-180 $\mu \mathrm{m}$ and virtually no fraction $>250 \mu \mathrm{m}$. This subdivision into 'lower Mol' and 'upper Mol' units also corresponds to a slight change in relative clay mineral proportions and in an increased potassium feldspar content in the $<32 \mu \mathrm{m}$ fraction in the upper part (Adriaens, 2015, p. 146). Within the 'upper Mol' Formation shallower than about $8 \mathrm{~m}$, an even coarser interval occurs with sand containing a significant fraction of grains $>500 \mu \mathrm{m}$ (Fig. 2).

The base of the 'clayey Kasterlee' unit of the Kasterlee Formation, as defined by the appearance of $>500 \mu \mathrm{m}$ size grains below, is situated close to $35 \mathrm{~m}$ depth. The transition to the Diest Formation below is confirmed by a marked change in mineralogy with a marked decrease in kaolinite, an increase in trioctahedral vermiculite, and the appearance of plagioclase (Adriaens, 2015, p. 146). In the 'clayey Kasterlee' unit the glauconite pellet content ranges from about $5-10 \%$ at the top to $30 \%$ at the base and pale grey clay layers occur over the whole interval. Detailed mineralogy shows that the lower $2 \mathrm{~m}$ of the 'clayey Kasterlee' unit consists for a significant part of reworked sand from the Diest Formation below (Adriaens, 2015, p. 146).

\subsection{The ON-Dessel-4 borehole stratigraphy}

At $14 \mathrm{~m}$ depth in the ON-Dessel-4 (Fig.1 nr 8) (031W053) borehole grain-size analyses show a boundary between a coarser 'upper Mol' unit with a large 250-500 $\mu \mathrm{m}$ fraction overlying a finer sized 'lower Mol' unit with a dominant 100-250 $\mu \mathrm{m}$ fraction. Traces of a $>500 \mu \mathrm{m}$ fraction occur only at about 8-9 $\mathrm{m}$ depth. As in the other ON-boreholes discussed above, the boundary of the 'lower Mol' unit with the 'clayey Kasterlee' unit $($ Plate $1 \mathrm{H})$ is put at the top of a sharp rise in GR at almost $30 \mathrm{~m}$. This is below the prominent colour change from grey-white above to green below which occurs at a depth of about $27 \mathrm{~m}$ and the occurrence of a marked clay-enriched level at $26.5 \mathrm{~m}$ (Plate $1 \mathrm{E})$. This short interval at the base of the 'lower Mol' unit with an increased GR, clay content and greenish colour is interpreted as reworked underlying Kasterlee sand comparable to the transition of the 'lower Mol' unit to the 'clayey Kasterlee' unit in the ONDessel-3 borehole (see 2.6.).

The top of the Diest Formation, based on the appearance of $>500 \mu \mathrm{m}$ sized grains is situated at about $35.5 \mathrm{~m}$. The modal size of the Diest Formation grain size is about $250 \mu \mathrm{m}$ and the 'clayey Kasterlee' unit modal size is $<200 \mu \mathrm{m}$. The pelletal glauconite content increases to about $20 \%$ in the Diest Formation while in the overlying 'clayey Kasterlee' unit it is much lower, except for the reworked sand at the base of the 'clayey Kasterlee' unit.

\subsection{The ON-Dessel-2 stratigraphy and comparison with the Louwye et al. (2007) interpretation}

Prior to the ON site characterization campaign in 2008 which yielded additional information based on a series of new ON boreholes, Louwye et al. (2007) already published a stratigraphic analysis of the ON-Dessel-2 borehole, already drilled in
2002, (Fig. $1 \mathrm{nr}$ 9) (031W0338) based on lithological and palaeontological data. The criteria for the interpretation of the boundaries developed in the present paper have been established after analysing the additional information that became available since 2008.

The marked increase in the GR signal, which is used as the main correlation level for the ON-boreholes in the area and interpreted as the boundary between the 'lower Mol' unit and the underlying 'clayey Kasterlee' unit, occurs at a depth of $29.5 \mathrm{~m}$ (level 1 in Fig. 2). The palynology also changes drastically at about the same depth. In the 'lower Mol' unit the pollen content increases strongly whilst the dinocyst content decreases and the very shallow water dinocyst Grammocysta verricula starts to appear (Louwye et al., 2007). In the cores peaty stripes are observed as well as an erosive level with burrows around $30.7 \mathrm{~m}$.

In the cores from about $9 \mathrm{~m}$ downwards the sand takes a pale greenish shine with still white intervals at $18 \mathrm{~m}$ and at $23-25 \mathrm{~m}$. As discussed above (see ON-Retie-2 and Introduction) the pale shine is inherited from some sparse decomposed glauconite pellets or from the green clay fraction in the sand washed into the drilling mud or from the clay suspended in the drilling fluid to start with. Above about $8 \mathrm{~m}$ depth occurs a coarse grained interval with a significant $>250 \mu \mathrm{m}$ and also $>500 \mu \mathrm{m}$ fraction even including dispersed fine gravel, comparable to the ON-Dessel-3 interval above $8 \mathrm{~m}$ depth. Therefore a distinction between a coarser 'upper Mol' unit with $\mathrm{a}>250 \mu \mathrm{m}$ fraction and 'lower Mol' unit without such fraction is put at this level 3 in Figure 2. In the palynology analysis the sand is completely barren above $17.5 \mathrm{~m}$. Pelletal glauconite content in the 'lower Mol' unit is very low and always below $1 \%$. Below, between $21 \mathrm{~m}$ and $27 \mathrm{~m}$ several levels with small clay fragments or clay pebbles occur as well as a few coarse sand levels with a $>250 \mu \mathrm{m}$ fraction. Also marked changes in the dinocyst content occur at about 26 and $30 \mathrm{~m}$ (Louwye et al., 2007) and at $26 \mathrm{~m} \mathrm{a}$ change in the relative proportions of the clay minerals is reported (Adriaens, 2015, p. 152). Between $24 \mathrm{~m}$ and $30 \mathrm{~m}$ a stepwise increase in hydraulic conductivity is measured (Beerten et al., 2010). The variability observed between about $23 \mathrm{~m}$ and the top of the 'clayey Kasterlee' unit at $29.5 \mathrm{~m}$ is interpreted as a reworked sand interval at the base of the 'lower Mol' unit and within it a particular erosive-reworking phase at about $26 \mathrm{~m}$. This variability in lithology explains the different interpretations of the top of the Kasterlee Formation by Louwye et al. (2007) and Adriaens (2015, p. 152) compared to the present interpretation.

A level within the 'clayey Kasterlee' unit occurs in which the $<62 \mu \mathrm{m}$ fraction represents more than half of the sediment. Pelletal glauconite content in the 'clayey Kasterlee' unit is between 2 and $7 \%$. The base of the 'clayey Kasterlee' unit and the top of the Diest Formation based on the appearance of $>500 \mu \mathrm{m}$ sized grains is interpreted at about $34 \mathrm{~m}$ (Adriaens, 2015, p. 152). This boundary is confirmed by a shift from fine sand with modal size $150-200 \mu \mathrm{m}$ to coarser sand below with modal size of about $280 \mu \mathrm{m}$ and accompanied by a marked drop in the GR value. Also the consistent appearance of smectite and vermiculite (Adriaens, 2015 , p. 152) characterizes the Diest Formation. Detailed mineralogical analysis of the cores allows to interpret a zone between $33 \mathrm{~m}$ and $35 \mathrm{~m}$ as reworked Diest Sand (Adriaens, 2015, p. 152). Vivianite concretions are common in the Diest Sand. Adriaens (2015, fig. 6.8) and Adriaens \& Vandenberghe (2020, fig.8, this volume) have published photographs of the Diest Fm, the 'clayey Kasterlee' unit and the basal part of the 'lower Mol' unit. Louwye et al. (2007) have interpreted the KasterleeDiest Formations boundary in a similar way and have correlated this boundary, based on palynology, with the gravel bearing Kasterlee-Diest Formations boundary in the Olen Albert Canal section (GRAN-GSB045W0253). The dinocyst association in the Kasterlee Formation between $34 \mathrm{~m}$ and $30 \mathrm{~m}$ has a normal shallow marine signature. The Diest and Kasterlee Formations, and also in the 'lower Mol' unit, hold a late Miocene assemblage. More precisely, the Diest Sand contains the DN9 zone of de Verteuil \& Norris (1996) whilst the 'clayey Kasterlee' and 'lower Mol' belong to the DN10 zone.

\subsection{The $\mathrm{ON}$-Dessel-5 borehole stratigraphy}

In the ON-Dessel-5 (Fig. $1 \mathrm{nr}$ 10) (031W0370) borehole (not shown in Fig. 2) no cores are available from the stratigraphic 
interval discussed and its stratigraphy is mainly based on the comparison of the GR and also RES log with the other boreholes in the area. At $13 \mathrm{~m}$ an 'upper Mol' unit can be distinguished from a 'lower Mol' unit by a break in the GR and RES log. The distinct level most prominent for correlation is the top of a 'clayey Kasterlee' unit expressed by the sudden increase in GR values at about $28.5 \mathrm{~m}$. Above this clay rich interval, a slight gradient in RES and GR values of a few $m$ thickness is interpreted as the expression of the presence of reworked sand at the base of the 'lower Mol' unit. The marked reduction in GR values at $33 \mathrm{~m}$, very similar to the evolution of the ON-Dessel-2 GR signal is interpreted as the top of the Diest Formation.

\subsection{The Donk and Pinken Sibelco sand pits}

On Figure 2 the grain-size evolution (fraction $>62 \mu \mathrm{m}$ ) is shown of the sand exploited in the Sibelco sand pits at Mol-Donk (Fig. 1 nr 11- Donk pit/ SIB-DON-02-03) and Dessel-Witgoor (Fig. 1 nr 12- Pinken pit/ SIB-PIN-03-03). The boundary between a 'lower Mol' and an 'upper Mol' unit, based on the appearance of a $>250 \mu \mathrm{m}$ fraction as defined in the ON-boreholes, can easily be identified at level 3 in Figure 2. This boundary seems to deepen eastwards. In the Sibelco Donk sand pit the 'upper Mol' sand has a mean grain size of about $300 \mu \mathrm{m}$ and the 'lower Mol' sand a mean of about $160 \mu \mathrm{m}$.

\section{Synthesis discussion of the stratigraphic results in the cored ON-boreholes in the Kasterlee-Retie-Dessel- Geel area}

\subsection{Stratigraphic synthesis}

A few metre of Quaternary sand deposits occur near the surface, consisting of loamy sand with various amounts of organic matter and characterised by high-chroma colours.

In common practice of lithostratigraphic borehole description the pale grey to white sand section with only rare glauconite pellets underlying the Quaternary will certainly be distinguished from the marked green glauconite bearing sediment below, justifying a lithostratigraphic boundary which is defining in this study the boundary between the 'lower Mol' unit and the 'clayey Kasterlee' unit. CPT records confirm the latter to be equivalent to the lower part of the type Kasterlee Formation near Kasterlee village.

Within the pale grey to white sand below the Quaternary until the marked increased GR level or the top of the 'clayey Kasterlee' unit, a systematic distinction can be made between a 'lower Mol' and an 'upper Mol' unit based on the appearance of a significant $>250-500 \mu \mathrm{m}$ fraction in the 'upper Mol' Formation. Towards the east this coarse fraction increases and it can make up more than half of the sediment and even a very coarse $>500 \mu \mathrm{m}$ fraction can be present (Fig. 2). Because their colour can hardly be distinguish in the core descriptions both units are labelled similarly, a 'lower Mol' and an 'upper Mol'. The label 'Mol' is used for these units as the 'upper Mol' unit is beyond doubt belonging to the classical Mol Formation as defined in the area. In Munsell terminology the colour of the dried 'lower Mol' Sand is light to yellow grey. Its $>62 \mu \mathrm{m}$ washed fraction is white and contains muscovite flakes and very rare glauconite grains but it lacks the speckled view caused by glauconite grains present in the Kasterlee Formation (see section 2.2. ON-Kasterlee-1 above and further text below). The clay fraction of the 'upper Mol' unit is pale grey while it is very pale green to light greenish grey in the Kasterlee Formation. Most likely, the green shine of the otherwise pale grey to white sand observed in several cores is inherited from the drilling mud in which sparse glauconite grains can become crushed or into which greenish clay particles are washed out of the sediment. Undoubtedly the green shine is analogous to the green colour of the drilling mud used by the Geological Survey of Belgium as criterion to determine the top of the Kasterlee Sand. The slight greenish colour occurring over a few metres at most in the base of the so defined 'lower Mol' unit (Plate 1E) is considered a reworking of the underlying 'clayey Kasterlee' unit. The presence of some metres of reworked sediment at the base of the 'lower Mol' unit also explains the common presence of a slight gradient in the GR and also RES curves at its base.

A marked increase in the GR signal allows a consistent identification of the top of the 'clayey Kasterlee' unit, part of the Kasterlee Formation (Fig. 2). Also Welkenhuysen \& De Ceukelaire (2009, p. 71-72) have identified the Kasterlee Formation in borehole logs in Geel (B/1-1100), Olen (B/1-1101a) and Meerhout (B/1-117a) (Fig. 1 nrs 13, 14, 15) based on the high GR interval. This clayey part of the Kasterlee Formation, the 'clayey Kasterlee' unit, is characterised by several percentages of pelletal glauconite, an increased clay fraction content, the presence of clay laminae, a marked greyish-yellowish-green colour (Munsell description on dried samples) and a speckled view caused by dark dispersed glauconite grains. The washed sand $(>62 \mu \mathrm{m})$ is very light to light green (Munsell description on dried samples) and speckled by glauconite grains. The separated $<2 \mu \mathrm{m}$ fraction is light green to light greenish grey (Munsell description on dried samples).

The presence of reworked Diest Formation sand at the base of the Kasterlee Formation is demonstrated by mineralogical analysis (Adriaens, 2015) and indicates an erosive phase between the deposition of both units and consequently justifies to consider Kasterlee and Diest Formations as separate lithostratigraphic units. The 'clayey Kasterlee' unit reflects a changing environment depositing finer sediments, more clay and less glauconite in the basin. This facies change is already observed in the sediments at the top of the Diest Formation in which also clay layers and finer sediments comparable to Kasterlee Formation sand occur in addition to very coarse sand laminae. Still, a boundary between the Kasterlee and Diest Formations can be consistently defined in the area by the appearance of a $>500 \mu \mathrm{m}$ fraction. In the present stratigraphic definitions neither the salmon colour of clays nor the presence of vivianite exclusively occur in the Diest Formation.

The top of the 'clayey Kasterlee' unit using the GR signature as defined above (Fig. 2) can consistently be identified in other boreholes in the area like ON-Dessel-1 (Fig. $1 \mathrm{nr}$ 16) (031W0300), ON-Mol-1 (Fig. 1 nr 17) (031W0314), VITO-KWO (Fig. 1 nr 18) (B/1-96240), even in large diameter Pidpa boreholes located about $5 \mathrm{~km}$ eastward of the ON-borehole area (Fig.1 nr 19- Pidpa (31e0418) and nr 20- WVP8 (B/1-96196)) with top 'clayey Kasterlee' interpreted at about $45 \mathrm{~m}$.

\subsection{The Kasterlee Formation interpretation in the cored ON- boreholes compared to the previous interpretation tradition in the Archives of the Geological Survey}

The above lithostratigraphic interpretation is different from the interpretation tradition in the same area used by Gulinck and collaborators at the Geological Survey and documented in borehole descriptions in the archives of the survey (see Introduction). This difference is most obvious in the stratigraphic interpretation of the Belchim (Fig. $1 \mathrm{nr}$ 1) (kb17d31W-B212) borehole by Gulinck et al. (1963) and of the Mol SCK 15 (Fig. $1 \mathrm{nr} 21)(\mathrm{B} / 1-0158)$ borehole by Gulinck \& Laga (1975). Referring to the Belchim borehole, Gulinck (1963, p. 32) reports that in the Mol area about $10 \mathrm{~m}$ of relatively coarse Mol Sand occurs above a fine sand unit that contains towards its base small glauconite grains, that it is of undetermined age and that therefore the meaning of the Mol Sand needs more precision. Shortly after, Gulinck et al. (1963), while interpreting that same Belchim borehole, decide to consider only the coarser upper part as Mol Sand and the finer sand of 'undetermined age' below as 'Casterlien'. He based this interpretation on the geometrical relationship with the type Kasterlee Sand from the Herentals-Kasterlee area, although he notes that the glauconite is almost absent in the Belchim borehole at the Mol nuclear site. Following this reasoning he is also interpreting the cored Mol SCK-15 borehole (Gulinck \& Laga, $1975)$ in the same way. There is no doubt seen the geographical location of the boreholes that this 'Kasterlee-sensu-Gulinck' sand interval corresponds to the finer grained 'lower Mol' unit as interpreted above in the ON boreholes; this same interval is interpreted in Wouters \& Schiltz (2012) as a Kasterlee sand unit lying above a clayey Kasterlee unit.

In the practice of the Geological Survey in the Campine area the appearance of a slight greenish colour in the drilling mud became the criterion to distinguish the $\mathrm{Mol}$ and the Kasterlee Sand as identified by Gulinck since 1963 (info P.L.). The faint pale green shine in some of the Mol Formation cores of the ON-boreholes discussed above casts doubt on the absolute stratigraphic value of this green shine; rare glauconite pellets 
occurring in this 'lower Mol' or 'Kasterlee-sensu-Gulinck' unit and abraded by drilling or the small pale green clay fraction in this unit resulting from reworked glauconite pellets (Adriaens et al., 2014) logically are responsible for this drilling mud colour but the eventual presence of suspended green clay in the original drilling fluid is unknown.

Clay lenses in the sections such as interpreted by Gulinck et al. (1963) to occur in the top of the Diest Sand, are in the present study interpreted to occur both in the Kasterlee Formation and in the Diest Formation. Gulinck and collaborators have consistently applied the interpretation scheme of a coarser Mol Sand overlying a finer pale grey to greenish-grey 'Kasterlee-Sand' (sensu Gulinck) with the presence of the majority of often coloured clay lenses in the top of the underlying Diest Sand (see for example boreholes Fig. 1 nr 22- Postel (kb9d18e-B30), nr 23- Overpelt (kb17d32e-B107), nr 24- Arendonk (1kb9d18w-B81), nr 25- Mol Rauw (kb17d31e-B279), nr 26- Mol Sas (kb17d31e-B280)). Due to the absence of borehole logs in many of these wells described by Gulinck and collaborators, their interpretation based on only lithology is hard to compare with GR-log-based interpretations as commonly used in the present study. For example just to the east of the Den Diel borehole (Fig. $1 \mathrm{nr} 56$ ), in the MolSas borehole (Fig. $1 \mathrm{nr} 26$ ) the dark green 'half-fine' sand with clay lenses which top is occurring at $-33.5 \mathrm{~m}$ TAW is described and interpreted by Gulinck (Archives of the Geological Survey of Belgium) as the Diest Sand-Kasterlee Sand boundary but it remains uncertain to decide whether this top does or does not correspond to the top of the GR increase occurring in the nearby Den Diel borehole at $-38.62 \mathrm{~m}$ TAW (Fig. 5) and interpreted in this study as the top of the 'clayey Kasterlee'. Such uncertainties or differences in interpretation of the Diest-Kasterlee Formations boundary can also explain how in the Retie-Mol area, a thin veneer of Diest Sand with dinoflagellate DN10 biozone is presented in Vandenberghe et al. (2014, fig. 3), whilst in the present study of the Olen (see section 4.1. below) and ON-Dessel-2 sections the boundary between both Formations coincides with the DN9DN10 biozones. In the light of this last result, the significance of the occurrence of biozone DN10 in the western part of the Campine Diest Sand wedge as in the boreholes Oostmalle and Kalmthout (Louwye \& Laga, 2008) needs further investigation.

The traditional interpretation of the 'Kasterlee-sensuGulinck' sand unit as the Kasterlee Formation is also followed in the 1:50 000 mapping of the Mol area using the difference in heavy mineral composition as an additional argument (Gullentops \& Vandenberghe, 1995b, p. 15), although the recorded heavy mineral differences could very well be the result of the major change in grain size.

\subsection{Discussion}

Possibly, as implied in the Gulinck interpretation, the pale grey 'lower Mol' unit or 'Kasterlee-sensu-Gulinck' unit in the ONborehole area represents a lateral evolution from the Kasterlee Formation sand speckled with glauconite in the reference area in the west by essentially losing its glauconite content. Consequently however in borehole descriptions this lateral pale grey-white facies becomes practically indistinguishable from Mol Sand and therefore lithostratigrapically it could be classified in the same unit together with the 'upper Mol' unit, the latter undisputedly always being described as Mol Formation in the area. On the other hand it cannot be excluded that the 'lower Mol' unit or 'Kasterlee-sensu-Gulinck' unit is effectively filling an erosive incision into the classical Kasterlee Formation that previously was extending more eastwards than Kasterlee village; in this situation no stratigraphic connection at all would exist between this 'lower Mol' unit or 'Kasterlee-sensu-Gulinck' unit and the Kasterlee Formation. Besides the very short distance between the hill N19g outcrop at Kasterlee village and the ON-Kasterlee-1 borehole, another argument for this erosion hypothesis could be the speckled character of the Kasterlee Sand in the N19g outcrop due to its about $5 \%$ pelletal glauconite content, similar to the content in the 'clayey Kasterlee' unit but unlike in the overlying 'lower Mol' unit in which pelletal glauconite is barely present (see above sections 2.2. ON-Kasterlee-1, 2.8. ON-Dessel-2...). The available CPT logs between the Kasterlee village hill and the ON-Kasterlee-1 borehole are not sufficiently decisive to discriminate between both possible interpretations either a lateral facies change or an erosive infill. Indeed where the CPT-derived k-logs (Fig. 3) suggest a close similarity between the 'lower Mol'/ 'Kasterlee-sensu-Gulinck' unit in the ON-Kasterlee-1 borehole and the Kasterlee Sand just below the Hukkelberg gravel in the $\mathrm{N} 19 \mathrm{~g}$ road outcrop, the cone resistance on the other hand suggests a difference. Cone resistance however is generally less reliable for such detailed correlation (Schiltz, 2020, this volume). The CPT patterns in the logs do show a continuity between the "clayey Kasterlee' unit as defined in the ON-boreholes and the more sandy base of the Kasterlee Formation in the reference section in the Kasterlee village hill (Fig. 3). It should also be noted that both the 'clayey Kasterlee' and the 'lower Mol' units hold the same dinocyst zonation DN10 constraining the timing of an eventual erosive boundary between both.

The CPT logs also confirm the geometrically lateral occurrence of the lower part of the Poederlee Sand above the Hukkelberg gravel in the hill and the 'upper Mol' Formation in the lower lying area east of the Kasterlee village as in the ON-Kasterlee-1 borehole. On the geological map sheet $17 \mathrm{Mol}$ (1:50 000) (Gullentops \& Vandenberghe, 1995a), the geometrical relationship between the Mol Formation, being the "upper Mol 'unit, and the Poederlee Formation is particular: where the occurrence of the Poederlee Sand stops at the eastern end of the Lichtaart-Kasterlee hill (Fig. 1), the Mol Formation on the map bends northwards, around the hill, to continue westwards along the north side of the Poederlee Sand hill. Therefore, on the geological map the 'upper Mol' Formation outcrop zone bends northwards around the end of the hill with the Poederlee Sand to continue westwards along the north side of the hill in contact with the Poederlee Sand. Geometrically and palaeogeographically most logical, the 'upper Mol' Formation is incising in the Poederlee Sand; however both units in that area have a similar late Pliocene age (Vandenberghe et al., 2004) and white sand nests of similar grain size and mineralogy as the glauconitic sand around have been described at the Hukkelberg gravel level in the Lichtaart sand pit Hoge Berg by Gullentops (1963) and recently at the same location and same level white slightly cemented sand nests similar to Mol sand have been observed by one of the present authors (R.H.) (Plate 1A), suggesting that interfingering between marine Poederlee sand and estuarine Mol sand might have occurred (see also Buffel et al., 2001b, fig. 3; and Vandenberghe et al., 2000, fig. 5). Gullentops \& Huyghebaert (1999, p. 194) already report that the Poederlee Sand registers the arrival of the Mol Sand in the subsiding Roer Valley Graben.

\section{The extension of the Kasterlee Formation from the Kasterlee type area to the surrounding areas}

\subsection{The Kasterlee Formation at Heist-op-den Berg and the Olen sluice}

To the southwest of the area discussed above, public works at the Olen sluice of the Albert Canal in 1972 (Fig.1 nr 29) (GRANGSB045W0253), have revealed an exceptional outcrop of the contact between Diest and Kasterlee Formations, namely a contact expressed by $\mathrm{cm}$-sized flint pebbles (Archives of the Geological Survey of Belgium, 045W0253). Such a base gravel in the Kasterlee Formation is unknown in the Campine to the north (Gulinck, 1963, p. 33). Palynological investigation of the section has confirmed a correlation with the Kasterlee-Diest Formation transition as observed in the ON-Dessel-2 borehole (Louwye et al., 2007). The interpretation of the dinocyst assemblages in the Olen section in terms of the de Verteuil \& Norris (1996) zonation indicates the limit between DN9 and DN10 to occur at or less than $1 \mathrm{~m}$ above the boundary gravel between the Diest Formation below and the Kasterlee Formation above the gravel (Louwye \& De Schepper, 2010; Louwye et al, 2007). The type Kasterlee Sand at Olen, above a thin veneer of reworked Diest Sand at its base, has a modal size of about $175 \mu \mathrm{m}$ and a pelletal glauconite content above 10\% (Adriaens, 2015, p. 16). The fine poorly glauconitic sand with clay lenses on top of the Heist-op-den-Berg and Beerzel hills southwest of Olen (Fig. 1; Plate 1C), were mapped by Gulinck (1963) as Kasterlee Sand ('facies Casterlien'). Note that Gulinck (1963, p. 33) correlates in this location the clay lenses in the fine sand with the Kasterlee 


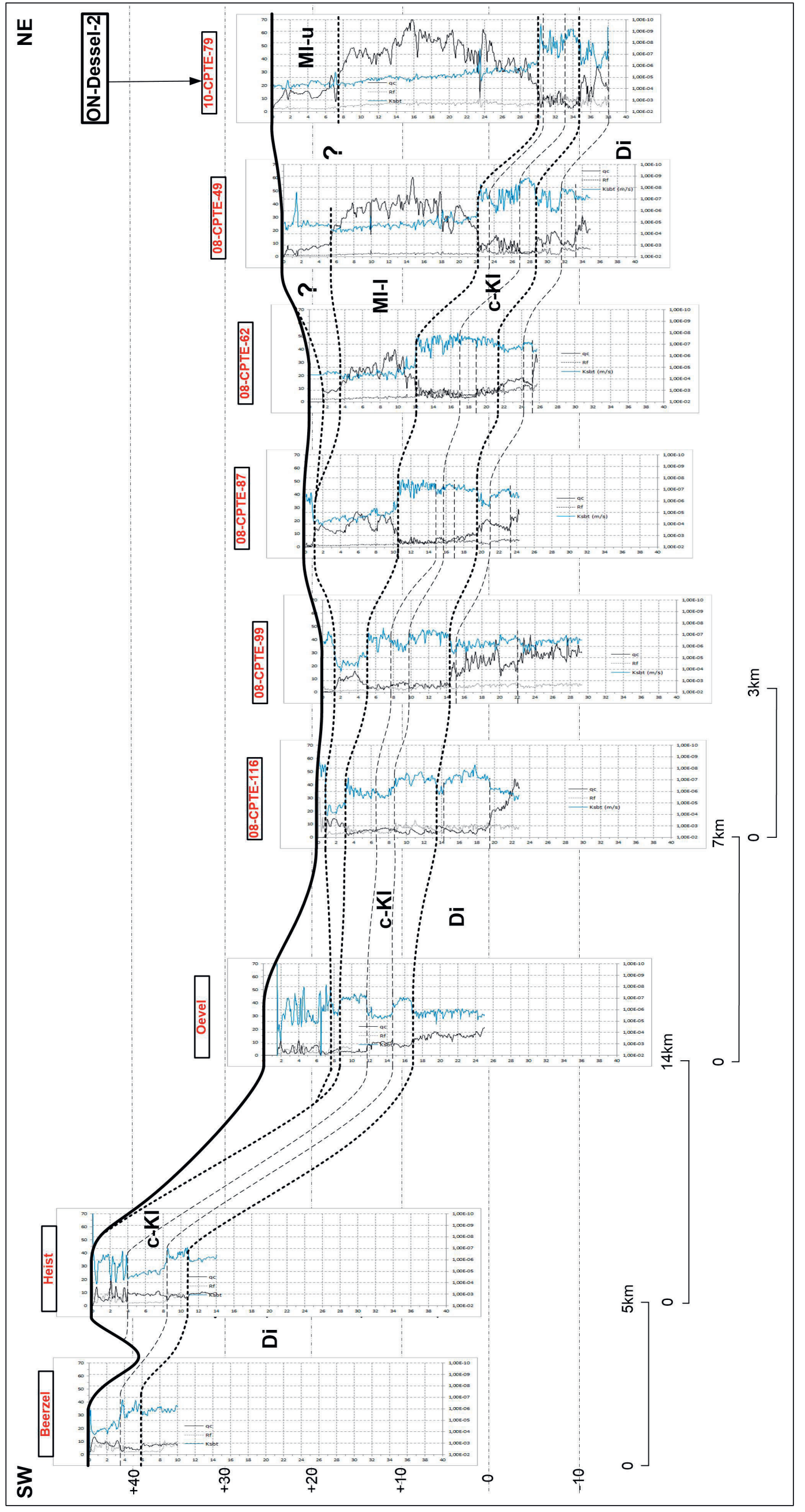

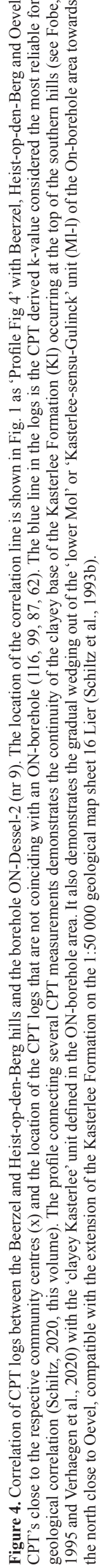


Sand in the Mol and Lommel areas, whereas in the borehole descriptions of these latter areas he usually ranges clay layers in the top of the Diest Formation. Remarkably he specifically notes (op. cit., p. 33) that this clayey facies occurs between the Mol Sand and the coarser Diest Sand. On the 1:50 000 map sheet 24 Aarschot, Schiltz et al. (1993a), lacking hard arguments for a Kasterlee Formation presence, ranked these Heist-op-denBerg and Beerzel hill sediments into the Diest Formation. Fobe (1995) and Verhaegen et al. (2014) however have convincingly confirmed the presence of the Kasterlee Sand on top of these hills. They distinguish a basal Hallaar Member with reworked Diest Formation sediment and above it the Beerzel and Heist-op-denBerg Members with about $200 \mu \mathrm{m}$ modal size, and respectively about $2 \%$ and $0.5 \%$ pelletal glauconite. In particular the newly observed basal gravel below the Kasterlee Formation at the top of the hills, with similar properties as the basal gravel layer in the Olen outcrop is convincing evidence to confirm the occurrence of the Kasterlee Formation on the top of these hills (Verhaegen et al., 2014). The occurrence of a basal gravel seems to be limited to the southern area between Olen and the Heist-op-den-Berg and Beerzel hills while northwards it is replaced by a hardly observable coarse sand grain horizon (see also Halet, 1935) making there a decision on the precise location of the boundary between the Kasterlee and Diest Formations more difficult. On Figure 4 a CPT-profile is shown linking the Heist-op-den-Berg hill with the ON-Dessel-2 borehole through Oevel, located east of the Olen sluice (Fig. 1). The several more clayey and sandy lithological subdivisions identified on top of the Heist-op-denBerg hill (Heist-op-den-Berg member) can be followed by CPT logs (Fig. 4) towards the 'clayey Kasterlee' Formation defined in the ON-borehole area confirming the presence of the Kasterlee Formation on top of the Heist-op-den-Berg and Beerzel hills and confirming also the correlation made by Gulinck (1963, p. 33). On the same CPT-profile (Fig. 4) the 'lower Mol', or 'Kasterleesensu-Gulinck', unit defined in the ON-borehole area can be observed extending and wedging out to the north in contrast to the 'upper Mol' unit which is limited to the ON-area itself as can be expected from the Mol Sand Formation extension on the geological map (Gullentops \& Vandenberghe, 1995a).

\subsection{The Postel-Lommel-Maaseik area}

Boreholes discussed in this area are located at the transition zone of the provinces of Antwerp and Limburg and between the Dutch border in the north and the zone around the Campine Canal in the south (Fig. 1). The most westward boreholes are close to and just west of the surface trace of the Mol Rauw Fault: the geophysically logged boreholes across the full Neogene section Den Diel (Fig.1 nr 56) (031E0337) and the ON-Mol-2B (Fig.1 nr 31) (031E0440) (and ON-Mol-2A just $20 \mathrm{~m}$ away), and the Sibelco (Fig. $1 \mathrm{nr}$ 30- ZEH08/05) (DOV ZEH08/05) pulsed slim hole with sediment analyses and geophysically logged but limited to $65 \mathrm{~m}$ depth (Vos, 2009) (Fig. 5).

In the ZEH08/05 pulsed cores close to the surface between 1 and $4 \mathrm{~m}$ occurs a black organic rich zone identified as the Maat lignite level (level 5 in Fig. 5). This identification is logically supported by the former near-surface exploitation of this lignite immediately south of the borehole (Den Diel Natural Reserve). Verbeeck et al. (2017) interpret as possibly Russendorp lignite their subunit A2, a 0.5 to $1 \mathrm{~m}$ thick layer of black detrital organicrich sand with some fine discontinuous clay lenses close to the surface at the site of the Mol Rauw Fault, the same location as ON-Mol-2A \& B, and labelled as level 6 with question mark in Figure 5; the Maat lignite in ON-Mol-2A \& B is put at a GR excursion at $9 \mathrm{~m}$ depth (level 5 in Fig. 5). At $20 \mathrm{~m}$ depth in ZEH08/05, and possibly at about the same depth in ON-Mol-2 A \& B, occurs a slight increase in GR that can be used as an unnamed stratigraphic reference horizon (labelled level 4 in Fig. 5). The grain size above and below this level 4 is barely different and the sand seems to be the eastward extension of the "upper Mol' unit defined in the ON-borehole area, becoming somewhat coarser in western direction towards the Donk and Pinken sand pits and the ON-Dessel boreholes (figured in Fig. 2). Between $34 \mathrm{~m}$ and almost $40 \mathrm{~m}$ depth in ZEH08/05 a clayey zone is indicated by the GR. This high-GR-interval marks also the top of a finer grain-sized sand unit below with modal size of about
$150 \mu \mathrm{m}$ and with only a minimal $>250 \mu \mathrm{m}$ fraction, while the 'upper Mol' sand unit above has a median size of about $250 \mu \mathrm{m}$ (Fig. 5). The drilling mud in ZEH08/05 also turns greenish at the top of this high-GR-interval and the sediment takes a 'light grey (green)' colour although no glauconite pellets are present (Vos, 2009 , p. 65). Therefore based on drilling mud colour and grain size it can be concluded that the section below $34 \mathrm{~m}$ in ZEH08/05 (level 3 in Fig. 5) has similar properties as the 'lower Mol' unit defined in the ON-borehole area discussed above and interpreted as 'Kasterlee sand' by Gulinck. In the Den Diel borehole a similar high-GR-interval occurs at about $25 \mathrm{~m}$ depth marking also the top of a finer-grained interval (level 3 in Fig. 5); the grain-size properties above and below this high-GR-interval are the same as above and below the top of the 'lower Mol' or 'Kasterlee-sensuGulinck' unit interpreted at a similar depth in the nearby Sibelco Pinken sand pit area (level 3 in Pin-03-3 on Fig. 2). Below about $60 \mathrm{~m}$ depth in ZEH08/05 (level 2 in Fig. 5) the grain size shifts to a slightly coarser size although at this level a slight increase of the GR signal occurs without an increase in the clay fraction. The same GR increase also occurs at about $60 \mathrm{~m}$ depth in ONMol-2B and at about 50m in Den Diel (level 2 in Fig. 5). The GR curve below this level 2 is slightly increasing downwards over about $20 \mathrm{~m}$. In the Den Diel borehole at $71.5 \mathrm{~m}$, a sharp and major GR value increase occurs to values in the same range as the GR increase interpreted as the top of the 'clayey Kasterlee' unit in the ON-boreholes (level 1 in Figs 2 and 5). In the ONMol-2B this GR jump occurs at $82 \mathrm{~m}$. Unfortunately the GR logs in ON-Mol-2 A \& B had to be run inside a metal casing with shoe at that same depth of the GR increase; however the $82 \mathrm{~m}$ GR increase occurs at a depth expected from the correlation of the levels 3 and 2 between Den Diel, ZEH08/05 and ON-Mol-2 A \& B (Fig. 5). Also the mud log of ON-Mol-2A reports at about $80 \mathrm{~m}$ depth a change from grey to green sediment and the start of a very clayey interval. Assuming a thickness of some metres for the 'clayey Kasterlee' Formation and its GR expression similar as in the ON-borehole area, the top of the Diest Formation in ONMol-2B should correspond to the first level of marked decrease in GR values (level 0 in Fig. 5) at some metres below the top of the 'clayey Kasterlee' unit.

In the Maatheide cored Sibelco borehole (Fig. $1 \mathrm{nr} 32-$ MHL03/1) (GEO-03/071-B2) at Stevensvennen to the southeast of the two boreholes (nrs 30,31) discussed above (Fig. 1) and east of the Mol Rauw and Reusel Faults, the Maat lignite occurs at 23-25m depth (Fig. 5). The sand above the Maat lignite (level 5 in Fig. 5) is traditionally called the Maatheide Member of the Mol Formation and the sand below it the Donk Member of the Mol Formation (Gullentops \& Vandenberghe, 1995b). The Maatheide Sand is clearly coarser grained than the Donk Sand (Fig. 5). The GR shows a marked increase at $35 \mathrm{~m}$ depth at the position of the unnamed stratigraphic reference level identified west of the Mol Rauw Fault (level 4 in Fig. 5) and an even larger GR excursion at $52 \mathrm{~m}$; the latter is considered equivalent to the clayey interval 34 $40 \mathrm{~m}$ in ZEH08/05 where the drilling mud was turning green and marking the top of the 'lower Mol' or 'Kasterlee-sensu-Gulinck' unit (level 3, see above). Inspection of the cores in MHL03/01 indicates that increased GR levels always appear to be clayenriched levels with organic layers or staining, as is also the case for the level 3 at about $52 \mathrm{~m}$. The labelling of the top organic black horizon in the MHL03/01 borehole (level 6 with ?, Fig. 5) as Russendorp lignite is only tentative because the Russendorp lignite is generally a rather black staining of the sand (Plate 1D) and in fact several of such stainings occur in the Mol Sand. The Maat lignite on the other hand can consistently be identified as lignite in the area of Mol Sand occurrence. For the original description of the Russendorp lignite in the Sibelco Maatheide sand pit, see Gullentops \& Vandenberghe (1995b, p. 27).

About $1 \mathrm{~km}$ eastwards of $\mathrm{ZEH} / 05$ and ON-Mol-2B, the Lommel (Russendorp) borehole (DOV kb17d31e-B323) (not displayed on the Fig. 5, logs available in the Archives of the Geological Survey of Belgium 031E0341) (location Fig. 1 nr 35) has a similar GR log as the ON-Mol-2B and ZEH08/05 with the Maat lignite in the Mol Formation at $32 \mathrm{~m}$ depth and with the top of the marked GR value increase representing the top of the 'clayey Kasterlee' unit at $92 \mathrm{~m}$. Analogous to the previously discussed boreholes, the interval between the top of the "clayey 


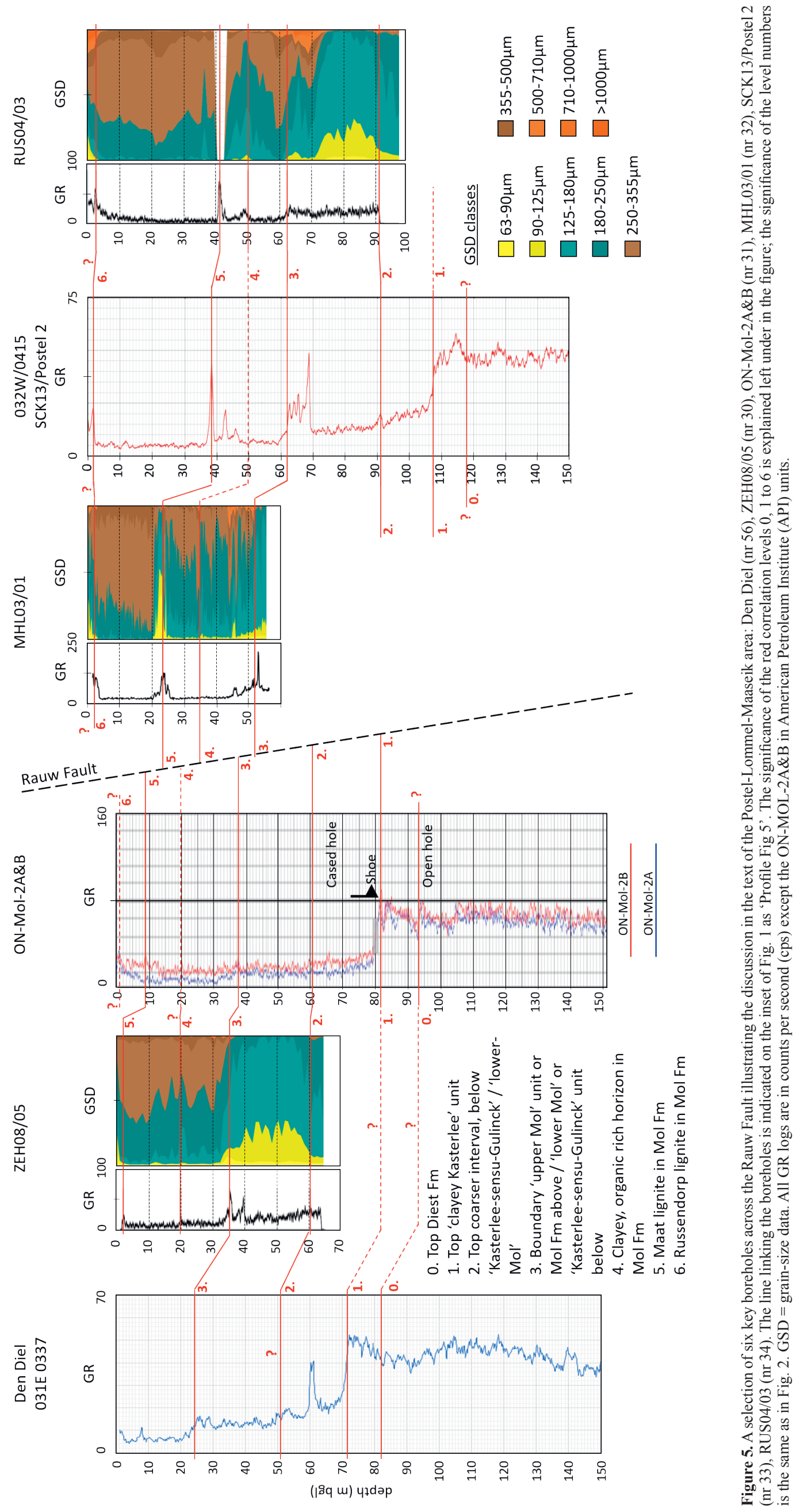


Kasterlee' unit and a high-GR-interval at $57-67 \mathrm{~m}$ is interpreted to represent in its upper part the 'lower Mol' or 'Kasterleesensu-Gulinck' unit as defined above with probably below it also the coarser interval (lines 1 to 2 interval of Fig. 5) although the log data have too low resolution in this borehole; the whole interval is interpreted as 'Kasterlee sand' by Laga (Archives of the Geological Survey of Belgium) although the stratigraphic uncertainty involved appears from the description of the same interval as 'Poederlee Sand or sandy top of Kasterlee Formation' by Envico (archives DOV kb17d31e-B323). Similarly to the ONboreholes discussed above, although no clear boundary with the Diest Formation underlying the 'clayey Kasterlee' unit can be distinguished, still below $92 \mathrm{~m}$ the GR values stay at their highest over several metre and delineate a slightly higher GR zone of 5-10 m thickness interpreted as defining the 'clayey Kasterlee' unit having about a similar thickness as in the ON- boreholes (Fig. 2) including the ON-Mol-2 A \& B (Fig. 5).

Near the provincial boundary between Antwerpen and Limburg close to the border of the Netherlands are located borehole SCK-13/Postel 2 (kb17d32w-B385; 032W0415) (Fig. $1 \mathrm{nr} 33$ ) and close-by the Sibelco RUS04/03 (DOV RUS04/03) (Fig. $1 \mathrm{nr}$ 34) pulsed slim hole, GR-logged and with sediment analyses but limited to $97 \mathrm{~m}$ depth (Vos, 2009) (Fig. 5). The GRlogs of both wells are very comparable with a $10 \mathrm{~m}$ thick and layered Maat lignite (level 5 in Fig. 5) at about 40 to $50 \mathrm{~m}$ depth (see also Gullentops \& Vandenberghe, 1995b, fig. 8), with the well-developed high-GR-interval between 62 and $69 \mathrm{~m}$ (level 3 at the top), and with the marked GR increase representing the top of the 'clayey Kasterlee' unit (level 1) at $108.5 \mathrm{~m}$ (see interpreted SCK 13/Postel 2 log in Vandenberghe et al., 2005, fig. 10). Between the 031E0341 (Lommel (Russendorp)) and 032W0415 (SCK13/Postel 2) boreholes, west of the Reusel Fault, Gullentops \& Vandenberghe (1995b, fig. 30) figure the position of the Russendorp lignite a few metre below surface and about $25 \mathrm{~m}$ above the Maat lignite. Vos $(2009$, p. 66) also interprets the clayey and organic rich interval between 5 and $9 \mathrm{~m}$ depth in RUS04/03 as the Russendorp lignite and the Maat lignite at about $41 \mathrm{~m}$ (Fig. 5); on the Figure 5 this Russendorp lignite (level 6) is indicated with question mark as tentative for the reason outlined above (see discussion of MHL03/01).

The drilling mud in RUS04/03 turns greenish at the welldeveloped high GR at $62 \mathrm{~m}$ (level 3 in Fig. 5) although no traces of glauconite pellets are present and the sands are described as 'light grey (green)' (Vos, 2009, p. 66). The interval below this high-GR-interval $62-69 \mathrm{~m}$ is therefore interpreted to represent the 'lower Mol' or 'Kasterlee-sensu-Gulinck' unit, confirmed by $\log$ response and grain size. The interval below has slightly higher GR values than above the high-GR-interval $62-69 \mathrm{~m}$ as is also the case in the Lommel (Russendorp) borehole. Grainsize data in RUS04/03 and ZEH08/05 are similar and the base of the 'Kasterlee-sensu-Gulinck' unit is tentatively put at the appearance of coarser sized sand at $91 \mathrm{~m}$ in RUS04/03 (level 2) and $60 \mathrm{~m}$ in ZEH08/05 (level 2 in Fig. 5). Below this level in the Postel 2 borehole a clear GR gradient exists extending till the top of the 'clayey Kasterlee' unit which is interpreted at the marked GR increase at $108.5 \mathrm{~m}$ (level 1 Fig. 5). In the Postel 2 section below $108.5 \mathrm{~m}$ the GR values stay at their highest until $117 \mathrm{~m}$ delineating a higher GR zone comparable to the GR signature of the 'clayey Kasterlee' unit above the Diest Formation in the ON-boreholes discussed. At about $4.5 \mathrm{~km}$ to the northwest of borehole SCK13/Postel 2 (032W0415), another borehole Postel (kb9d18e-B30) (Fig. $1 \mathrm{nr} 22$ ) was drilled till $110 \mathrm{~m}$ depth with cores described by Gulinck (Archives of the Geological Survey of Belgium 018E0097) but without geophysical logs at that time. Following his traditional interpretation the whole pale grey to green fine sand interval between 49 and $102 \mathrm{~m}$, below the coarser Mol Sand, is interpreted by Gulinck as 'Kasterlee sand'; within this sand a gravelly coarse sand horizon occurs at $75 \mathrm{~m}$. Between $97 \mathrm{~m}$ and $106 \mathrm{~m}$ in this Postel borehole a clayey interval is described the top of which is undoubtedly corresponding to the marked GR increase in the logs of the SCK-13/Postel 2 borehole and considered in the latter as the top of the 'clayey Kasterlee' unit. This clayey interval is subdivided by Gulinck in two parts: an upper part between 97 and $102 \mathrm{~m}$ ranged in his defined Kasterlee sand with green and grey clay in fine green sand at the base and a lower part with purple clay lenses in dark green sand below and interpreted by Gulinck as the top part of the Diest Sand.

Between the previously discussed SCK13/Postel 2 borehole and the Lommel 2 (kb17d32w-B379; 032W 409) (Fig. 1 nr 36) borehole close to the Dutch border in the north of the Riebosserheide occur the Reusel and Aa faults. Still the log signature of both wells remains similar but the marker levels such as the Maat lignite, the high-GR-interval and the top of the "clayey Kasterlee' unit interpreted as the marked GR increase level, are shifted to deeper levels in the Lommel 2 borehole (Fig. 6 based on Vandenberghe et al., 2005, fig. 10). To the southeast of these boreholes Gulinck (1963) (Archives of the Geological Survey of Belgium) describes in the Overpelt (032E0128) (Fig. $1 \mathrm{nr} 23$ ) cored borehole between $36.5 \mathrm{~m}$ and $71 \mathrm{~m}$ a pale grey-green, mica-rich sand without glauconite pellets as Kasterlee Formation confirming his interpretation tradition of such pale sand below the pale grey coarser Mol Sand which contain very coarse sand incursions especially near the base, and above the dark green and bioturbated Diest Formation which contains some clay layers in its top. Based on grain size, this Kasterlee unit in the Overpelt borehole consists of two subunits: between $36.5 \mathrm{~m}$ and about $50 \mathrm{~m}$ the sand has a median of about $150 \mu \mathrm{m}$ whilst below it has a markedly coarser median size.

More eastward in the Roer Valley Graben (RGV) beyond the Lommel-Grote Brogel fault zone (Fig. 1) a stratigraphic correlation was proposed between the Postel 2 and Lommel 2 boreholes discussed above and the cored and logged Maaseik (kb18d49w-B220) (Fig. $1 \mathrm{nr} 37)$ borehole in Vandenberghe et al. (2005, fig. 10) (adapted version in Fig. 6). The sudden increase in GR value, demonstrated in the ON-borehole area to be the top of a 'clayey Kasterlee' unit and interpreted in the same way around the Mol Rauw Fault zone and further to the east in the Postel and Lommel area, has definitely another lithostratigraphic meaning in the cored Maaseik borehole (049W0220) where it was labelled as the top of unit X in Vandenberghe et al. (2005, fig. 10; Fig. 6). The about $6 \mathrm{~m}$ thick bed $\mathrm{X}$ in the cores of the Maaseik borehole, occurring below white-grey and lignitefragment-bearing sand of the Kieseloolite Formation, has a high GR signature but consists of a yellowish-grey mica-rich compact sand with modal size between 128 and $174 \mu \mathrm{m}$ with less than $4 \%$ glauconite grains, a very different lithology compared to the 'clayey Kasterlee' unit. A palynological reinvestigation of newly sampled sediment (Louwye, 2020a, this volume) indicates that bed $\mathrm{X}$ is of almost latest Tortonian age; it contains a dinoflagellate association corresponding to the DN9 dinocyst biozone of de Verteuil \& Norris (1996), the Danish H. obscura zone of Dybkjaer \& Piasecki (2010) and the German biozonation by Köthe (2012). Therefore bed $\mathrm{X}$ is a lateral time equivalent of the Diest Sand in the Campine area to the west and older than the 'clayey Kasterlee' unit (see also Verhaegen, 2020). In the Maaseik borehole bed X overlies the green glauconitic 'Breda Formation' which contains in this borehole a biostratigraphic signature of the Deurne-Dessel Members of the Diest Formation; in the area discussed to the west a progressively stratigraphically younger part of the Diest Formation occurs below the classical Kasterlee Formation (see Vandenberghe et al., 2014, fig. 3). In the Maaseik borehole, the Kieseloolite Formation overlying bed $\mathrm{X}$ has an erosive base. Its lower part contains lignite fragments and abundant very coarse sand; based on the RES log, this part could be split off from the Waubach Sand and Gravel unit in which it was incorporated by Vandenberghe et al. (2005, fig. 10). Although more sedimentological and biostratigraphical calibration is needed and thickness differences are apparent, a separate correlation of this individualized $25 \mathrm{~m}$ thick lower part to the Lommel-Postel area can be attempted through the Kinrooi (kb18d49W-B230) (Fig. $1 \mathrm{nr} 40$ ), Bocholt (B/7-0356) (Fig. $1 \mathrm{nr}$ 38 ) and St. Huibrechts Lille (kb18d33w-B142) (Fig. 1 nr 39) boreholes using the RES and GR logs (see Vandenberghe et al. 2005, fig. 10) (Fig. 6) as is already done in the interpretation and mapping practice for the H30 Roerdalslenk and Kempen projects (Deckers et al., 2014; Vernes et al., 2018). The RES curve, and somewhat less outspoken also the GR log, between the lower limit of the Brunssum complex and the top unit X (Fig. 6) has a very similar twofold character in the Maaseik and Kinrooi boreholes, both in the same tectonic block, and the top of the lower lobe can 


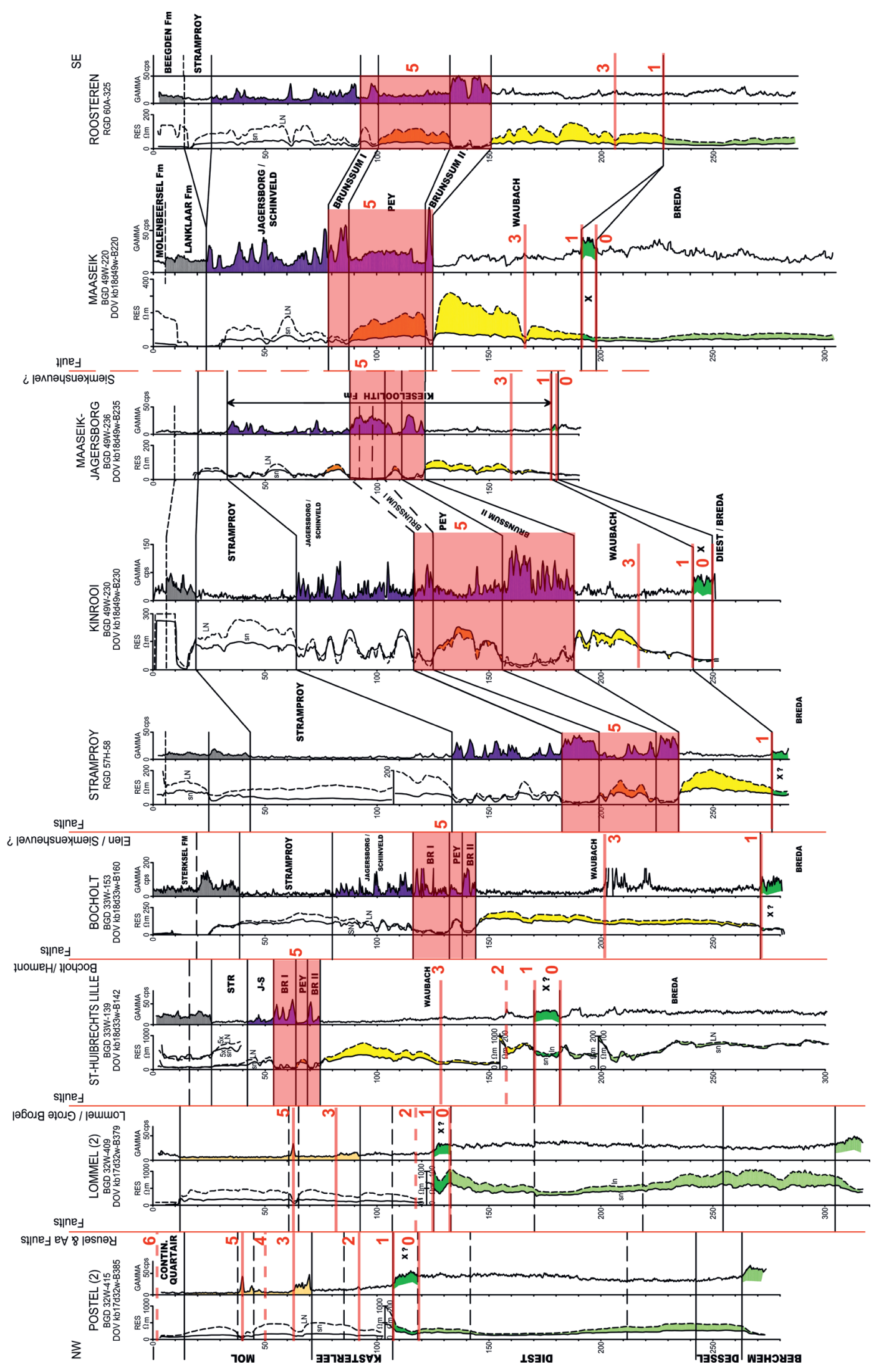

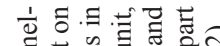

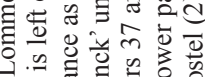

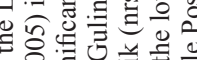

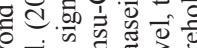

ब吅

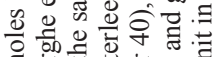

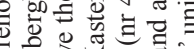

흘 은

60

包. 在

글

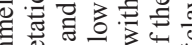

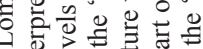

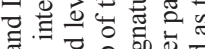

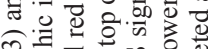

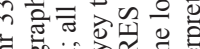

选.

ब

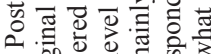

을 흘

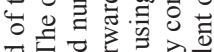

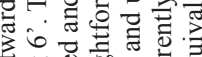

的然.

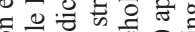

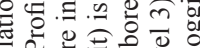

的政全

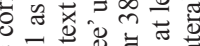

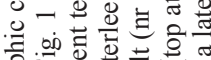

일

等

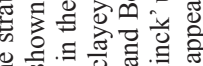

较

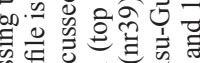

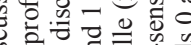

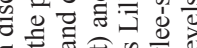

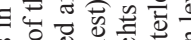

\%

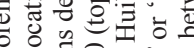

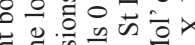

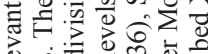

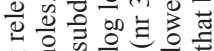

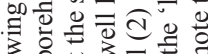

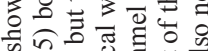

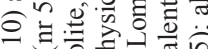

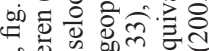

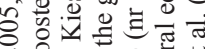

d d

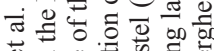

证

政。目

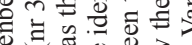

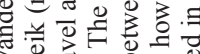

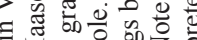

之唔

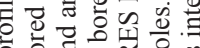

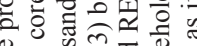

正

o 政

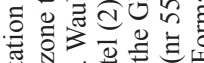

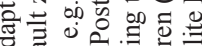

听

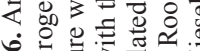

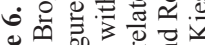

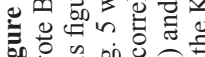

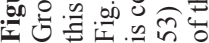


easily be identified in the Kinrooi borehole at about 219 m depth; the Kinrooi and Maaseik Jagersborg (kb18d49W-B235) (Fig. 1 nr 53) have a similar twofold log signature in that interval (Fig. 6). In the Bocholt borehole the thickness between the base of the Brunssum complex and the top of the bed $\mathrm{X}$ has almost doubled compared to the Maaseik borehole; an explanation could be the intense fault activity in the area. Still it is reasonable to interpret the same twofold subdivision in the RES and GR logs in the Bocholt borehole with the top of the lower lobe occurring at about $200 \mathrm{~m}$ depth. However the top of this lower lobe also includes about $20 \mathrm{~m}$ of a very layered high GR signal. In the St. Huibrechts Lille borehole the top of the lower RES lobe can be identified at $130 \mathrm{~m}$ whilst the high GR of the top of bed X could be either 160 $\mathrm{m}$ or $170 \mathrm{~m}$ (as in Vandenberghe et al., 2005, fig. 10). Applying the same criterion in the RES curve to identify the top of the lower lobe as individualized in the Maaseik well, situates the top of the lobe in the previously interpreted Lommel 2 and Postel 2 boreholes (see above) at respectively about $91 \mathrm{~m}$ and about $67 \mathrm{~m}$ (level 3 in Fig. 6). It is remarkable that coinciding with the top of this lower lobe in both boreholes occurs the almost $10 \mathrm{~m}$ thick higher-GR-interval discussed above and shown in Figure 5; this clayey interval was shown to occur at the top of the 'lower Mol' or 'Kasterlee-sensu-Gulinck' unit (level 3). In conclusion it can be argued that the lower lobe of what was previously interpreted in Vandenberghe et al. (2005) as the lower part of the Waubach sand and gravel, geometrically correlates to the 'lower Mol' or 'Kasterlee-sensu-Gulinck' unit in the west. However more data are required to substantiate the proposed possible lateral equivalence; the base of the Waubach unit in the Maaseik well at 191 and $191.5 \mathrm{~m}$ still has the dinocyst association DN9 of almost latest Tortonian, the same as in bed X (Louwye, 2020a, this volume) while the DN10 dinocyst biozone in the 'clayey Kasterlee' and in the 'lower Mol' or 'Kasterlee-sensu-Gulinck' units in the area to the west is latest Tortonian and mainly Messinian in age. Heavy minerals in the upper part of the Waubach unit are comparable to the heavy minerals in the 'Kasterlee-sensu-Gulinck' or 'lower Mol' unit and in the Mol Formation (Verhaegen, 2020). It should be noted that the base of the Kieseloolite Formation, of which the Waubach unit is the oldest unit, is considered to start indeed in the late Miocene by de Mulder et al. (2003, p. 317). In the Maaseik borehole the palynology suggests rather a Pliocene age for the whole Kieseloolite section (Vandenberghe et al., 2005, p. 34 ) and the lignites between about 55 and $88 \mathrm{~m}$ could correlate with the Maat lignite (Vandenberghe et al., 2005, fig. 2 and p. 14). In the Lower Rhine Basin (NW Germany) the Tortonian is made up by three sequences of the Inden Formation consisting of stacked meandering channels and floodplain deposits (Schäfer et al., 2005; Schäfer \& Utescher, 2014; Utescher et al., 2012); the chronostratigraphic range of the DN9 dinocyst zone identified in Diest Sand and in bed X in the Maaseik borehole points to an approximate correlation with the middle Inden sequence $(7 \mathrm{C}, \mathrm{D})$ as determined by Utescher et al. (2012, fig. 3) in the Inden open cast pit. The DN10 dinocyst biozone association in the 'clayey Kasterlee' and 'lower Mol' or 'Kasterlee-sensu-Gulinck' units is mainly Messinian in age; the start of the Messinian in the Lower Rhine Basin is characterised by the sudden appearance of coarse braided river sand (Hauptkies) marking the progradation of the coastline to the northwest (Utescher et al., 2012).

Boreholes and outcrops west of Maaseik and west of the major Grote Brogel fault, described in the field guide part of the Legend Geological Map Rekem 26 (Buffel et al., 2001a) are harder to fit in the above discussion because they lack the geophysical logs used as a main correlation tool in this paper. Borehole descriptions by Gulinck in the Archives of the Geological Survey of Belgium of for example Hechtel (kb17d47e-B186; 047E0192) (Fig. $1 \mathrm{nr}$ 41), Wijshagen (kb18d48w-B181; 48W 180) (Fig. $1 \mathrm{nr} 42$ ) and Helchteren (kb25d62e-B265; 62E 261) (Fig. $1 \mathrm{nr} 43$ ) boreholes report 'Kasterliaan' of respectively $48 \mathrm{~m}, 28 \mathrm{~m}$ and $17.5 \mathrm{~m}$ thickness; the lithology described is greenish but also pale and white and glauconite is not reported as an important component. In the upper part of the Opitter Molen (GSB048e0151C) sand pit (Fig. $1 \mathrm{nr} 44$ ), $3 \mathrm{~m}$ of fine homogeneous sand with median about $170 \mu \mathrm{m}$, glauconite content of 5 to $20 \%$ with concentrations in a few horizons, erosive bedding at the base and a unidirectional oblique stratification is overlying the Diest Formation (description and analyses in Gullentops, 1963) and interpreted as Kasterlee Formation by Buffel et al. (2001a, Stop 5 p. 47). However these authors also recognize that the unit described as Kasterlee sand in the area of the map sheet Rekem 26 is different from a typical Kasterlee Formation and therefore even a new name was introduced, the Dorperberg sand. The units described by these authors as the Gruitrode Mill member of the Diest Formation and the Dorperberg member of the Kasterlee Formation, are physically separated from the top of the underlying Bolderberg Formation by an about $75 \mathrm{~m}$ thick package of sandy sediments, the base of which was shown at the Wijshagen borehole site to correlate to the Diest Formation (Louwye \& Laga, 2008). Houthuys \& Matthijs (2020, this volume) also studied the Opitter Molen and Solterheide (GSB048e0296) (Fig. $1 \mathrm{nr}$ 45) sand pits and argue the Dorperberg member probably correlates to a perimarine incursion inserted in or on top of the lower part of the Mol Sand.

\subsection{Extension to the west and the north of the ON-boreholes}

Westward of Kasterlee village, the typical Kasterlee Formation, defined as fine green glauconitic sand below the Hukkelberg gravel and above the coarser Diest Formation has been reported and described from several locations. From the Lichtaart sand pit (Fig. $1 \mathrm{nr} 27$ ) Gullentops (1963, fig. 7) reports a modal size of $160-170 \mu \mathrm{m}$, absence of fraction $>250 \mu \mathrm{m}$ similar to the 'Kasterlee-sensu-Gulinck' defined above, glauconite $<5 \%$ and an exceptionally large hornblende content (Geets, 1962; Gullentops, 1963); colours of the sand in the sand pit are variable (Plate 1A). From the Gierle (kb8d17w-B14) (Fig. $1 \mathrm{nr} 46)$ borehole, Gullentops \& Huyghebaert (1999) report a modal size of $130 \mu \mathrm{m}$ and $25-30 \%$ glauconite content (Gullentops \& Huyghebaert, 1999), and from Oud-Turnhout (kb8d17e-B497) (Fig. $1 \mathrm{nr} 47$ ) and Rees (kb8d17e-B495) (Fig. $1 \mathrm{nr} 48$ ) a modal size between $125-250 \mu \mathrm{m}$ and a thickness of about $10 \mathrm{~m}$ is reported (Buffel et al., 2001b; Louwye \& De Schepper 2010). Louwye \& De Schepper (2010) have established a Messinian age for the Kasterlee Formation in the Oud-Turnhout borehole identifying the DN10 dinocyst biozone of de Verteuil \& Norris (1996). They can correlate the Kasterlee Formation identified in the Oud-Turnhout well with the Kasterlee Formation identified in the Olen Sluice outcrop and the ON-Dessel-2 borehole discussed above, thereby supporting the lithostratigraphic identification and correlation of the Kasterlee Formation in the region Kasterlee-Olen-LichtaartTurnhout and the ON-borehole area. Further westwards than this area the Kasterlee Formation is no longer identified and the boreholes discussed above represent the most westward known occurrence of the Kasterlee Formation. Further westwards between Turnhout and Antwerp the Pliocene Kattendijk Sand is found systematically overlying the Diest Formation on the 1:50 000 regional geological maps and profiles (see also Houthuys et al., 2020, this volume). The palaeontologically barren Kasterlee Sand was traditionally considered equivalent to the lower Pliocene Kattendijk Sand (Gulinck, 1963, p. 33) because both glauconitic sand units are overlying Diest Sand and occur laterally of each other. However more recent dinoflagellate cyst investigations (Louwye et al. 2007; Louwye \& De Schepper, 2010; Louwye et al., 2020b, this volume) have attributed a late Miocene age to the Kasterlee Sand whilst the lower Pliocene age of the Kattendijk Sand is confirmed (Louwye et al., 2020c).

North of Oud-Turnhout, close to the boundary with the Netherlands and west of Poppel, in the flushed $300 \mathrm{~m}$ deep borehole Weelde (kb8d8e-B26) (Fig. $1 \mathrm{nr} 49$ ), Laga \& Notebaert (1981) (Archives of the Geological Survey of Belgium 008E 0133) distinguish the Pliocene glauconitic Lillo Formation $(67-87 \mathrm{~m})$ with shell debris and lower GR values from the underlying $15 \mathrm{~m}$ thick Kattendijk Formation with higher GR reading and less shell debris. Closer to the type area of both units in the west, this GR reading relationship between the Lillo and Kattendijk Formations is also documented in the Wuustwezel (GSB015E0298A) (Fig. 1 $\mathrm{nr}$ 50) borehole (Jacobs et al., 2010, p. 33). In the Verrebroek dock in the Antwerp harbour area (Antwerp in Fig. 1), the glauconite content of the Kattendijk Formation is about $20 \%$ whilst in the overlying Lillo Formation it is only $5-10 \%$. In the Weelde borehole the presence of shell fragments shallower than $102 \mathrm{~m}$ makes that no Kasterlee Formation is expected above $102 \mathrm{~m}$ 
depth. Below this depth Laga \& Notebaert (1981) describe $31 \mathrm{~m}$ of poorly glauconitic fine clayey and also carbonate containing homogeneous sand that is given the name of the Poppel sand facies as the upper part of the Diest Formation. The Poppel sand facies is delineated by a low GR and high RES log signature and the Diest Sand below the Poppel facies contains more glauconite and its top at $133 \mathrm{~m}$ depth is marked by a GR increase. A more recent drilling campaign by SCK at Weelde-vlieghaven (kb8d8e-B161) (Fig. 1 nr 51) shows comparable borehole logs in the interval discussed as in the Weelde (008E0133) borehole located more to the north, but unfortunately the stratigraphy in the interval of interest was not studied. On regional profiles drawn in the mid and late 1970s by Laga for the Ground Water Commission of the Province of Antwerp (Archives of the Geological Survey of Belgium), the Poppel facies first described in 1981 (see above) obviously is not yet indicated but on the profiles by Laga (1976) PGL/76/106/3 (Poppel-Ravels-Turnhout) (Fig. 7a) and PGL 76/106/2 (PoppelRavels-Dessel) (Fig. 7b), geometrically, this Poppel facies would have been included in about $45 \mathrm{~m}$ of fine glauconitic sand interpreted as Kasterlee sand below the shell debris containing Lillo Formation and overlying the Diest Formation; on another profile PGL/74/105 (Archives of the Geological Survey of Belgium) the relay of Kattendijk Sand in the west by Kasterlee Sand in the east is shown to occur around Weelde. On a profile linking the Belchim (Eurochimic) borehole and a deep hole at Poppel, Gulinck (1963, fig. 4 p. 39) shows the occurrence and rapid thickening of the Lillo Formation ('Scaldesian') north of Arendonk towards Poppel (Fig. 1). In the borehole Arendonk (018W0197) (Fig. $1 \mathrm{nr} 24)$, Gulinck (Archives of the Geological Survey of Belgium) interprets $22.5 \mathrm{~m}$ of fine green homogeneous slightly clay containing sand as the Kasterlee Formation between coarser glauconite-rich Diest Sand below and a thin layer of 'Scaldesian' above it.

\section{Discussion}

The main motivation to start the present study has been the uncertainty in the interpretation of what was expected to be the classical stratigraphic succession from a Diest Sand below over Kasterlee Sand to Mol Sand above in a series of cored and geophysically logged boreholes in the area of Kasterlee, Geel, Retie, Mol and Dessel.

A coherent stratigraphic subdivision based on grain size and GR signature was established for that area that could be used for correlating the boreholes as shown in Figure 2. In the basal part of the boreholes, the appearance of grains $>500 \mu \mathrm{m}$ was found to be a reliable criterion to pick the boundary between the Diest Formation and the 'clayey Kasterlee' unit which is part of the classical Kasterlee Formation. In fact Gulinck (1963) already noted that the clayey facies of the Kasterlee Formation at the top of the Beerzel and Heist-op-den-Berg hills also occurred in the Mol, Leopoldsburg and Lommel area. At the base of the 'clayey Kasterlee' unit reworked sediment from below can occur and even a thin veneer of coarse reworked sand can be present. Neither presence or colour of clay layers nor the presence of vivianite concretions are found to be reliable criteria to distinguish between Diest and Kasterlee Formations. The top of the "clayey Kasterlee" unit of the Kasterlee Formation is put at the most marked increase in the GR signal, a level generally well expressed and most useful for regional correlation. We have labelled this unit as 'clayey Kasterlee' unit because it contains a significant size fraction $<63 \mu \mathrm{m}$, more than in the Kasterlee Sand of the type area. This 'clayey Kasterlee' unit is differentiated from an overlying unit labelled in this study 'lower Mol' Formation although in the practice of the borehole interpretation in the area by the Geological Survey of Belgium, followed by the authors of the 1:50 000 Geological Map sheet 17 Mol (Gullentops \& Vandenberghe, 1995a; 1995b), included this 'lower Mol' unit in the Kasterlee Formation. Therefore in the present paper we have systematically labelled this 'lower Mol' unit also as 'Kasterleesensu-Gulinck' unit both as equivalent terms. The reason to rather associate this unit with the classical Mol Formation is its pale grey colour that not only makes it difficult to differentiate it from the overlying 'upper Mol' unit which is beyond doubt part of the genuine Mol Formation mapped in the area, but in addition it also contrasts in the cores with the underlying light green 'clayey Kasterlee' unit, belonging to the genuine Kasterlee Formation (Plate 1F, G). The low GR signal of this 'lower Mol' unit is also very similar to the GR signal of the Mol Formation and contrasts with the marked high GR of the 'clayey Kasterlee' unit below which is not only due to its higher clay content but also to its higher glauconite content. Except from some rare grains, pelletal glauconite is absent in the 'lower Mol' Formation. However the small clay quantities in the 'lower Mol' unit have a pale green colour making the drilling mud and the cores to shine faintly greenish. The appearance of green drilling mud was considered in the practice of borehole description in the Campine as the criterion to define the top of the Kasterlee Formation. The clay fraction of the 'upper Mol' unit has a pale grey colour. The base of the 'lower Mol' unit has an erosive contact with the underlying 'clayey Kasterlee' unit explaining the presence of some reworked greenish sediment at the base of the 'lower Mol' unit (Plate 1E, F). The boundary between the 'lower Mol' and 'upper Mol' units is picked where upwards in the section a significant fraction $>250$ $\mu \mathrm{m}$ appears. Towards the east in the Dessel area this fraction often becomes dominant with even significant $>355 \mu \mathrm{m}$ and $>500$ $\mu \mathrm{m}$ fractions (Fig. 2).

Further eastwards, towards the Mol Rauw Fault area and beyond it towards the Postel-Lommel area, the 'lower Mol' or 'Kasterlee-sensu-Gulinck' unit can systematically be recognized deeper in the subsurface by its characteristic well-sorted and fine grain size lacking a fraction $>250 \mu \mathrm{m}$ (Fig. 5). In this area the drilling mud turning green at the top of the 'lower Mol' unit or 'Kasterlee-sensu-Gulinck' unit has been observed confirming the equivalence of both unit name labels; the 'upper Mol' unit becomes thicker and a marker within it is the clayey Maat lignite horizon recognized by its pronounced increased GR signal. In current stratigraphic practice the 'upper Mol' sand below the Maat lignite is the Donk Sand and the sand above it, up to the Russendorp lignite, is called the Maatheide Sand. Both are members of the Mol Formation. The former appears slightly finer sized than the latter (Fig. 5). In the top of the 'lower Mol' unit appears a several metre thick layered clayey interval marked by an increased GR signal. Also downwards, above and till the typical marked GR increase level of the top of the 'clayey Kasterlee' unit, occurs a coarser sand unit about 15-20 m thick between levels 1 and 2 in Figure 5. In this area, analogue to the Kasterlee-Dessel area (Fig. 2), the somewhat more elevated signal in the upper 5 to 10 $m$ of the high GR section is interpreted as delineating the "clayey Kasterlee' unit above the Diest Formation.

Even in the subsurface east of the Grote Brogel Fault elements of the stratigraphic succession outlined above can be observed (Fig. 6). There is the marked increase in GR signal on top of the unit labelled X (see in Vandenberghe et al. 2005, fig. 10) analogous to the top of the 'clayey Kasterlee' unit which is of comparable thickness as bed X. However the bed X in the Maaseik well is a slightly glauconitic but very mica-rich pale coloured sand, older than the 'clayey Kasterlee' unit (DN10) and rather correlating in time with the Diest Sand (DN9) in the Campine area to the west. Also the clayey interval well developed in the top of the 'lower Mol' or 'Kasterlee-sensu-Gulinck' unit in e.g. the Postel 2 borehole is very well developed in the Bocholt borehole (Fig. 6). In particular the evolution of the RES log above and below this clayey interval allows to split the Waubach unit as described before in Vandenberghe et al. (2005) into an upper part being the genuine coarse-grained Waubach unit and a lower part possibly equivalent to the 'lower Mol' or 'Kasterlee-sensuGulinck' unit including the latter's lower coarser part as identified between level 1 and 2 in Figure 5. West of the Grote Brogel Fault the Maat lignite is a characteristic subdivision within the 'upper Mol' unit while east of this Fault it is replaced by a complex of clay, sand and peat layers (Brunssum) the palynology of part of which is known to correspond to the palynology of the Maat lignite.

In the type area of the Lichtaart-Kasterlee hill ridge, Kasterlee Formation sediments are described as glauconitic fine sand lacking carbonate shelled fossils overlying coarser Diest Formation sand and underlying the Hukkelberg Gravel in the type locality. This hill however ends at the Kasterlee village and with it also the occurrences of the Hukkelberg gravel and the Poederlee 

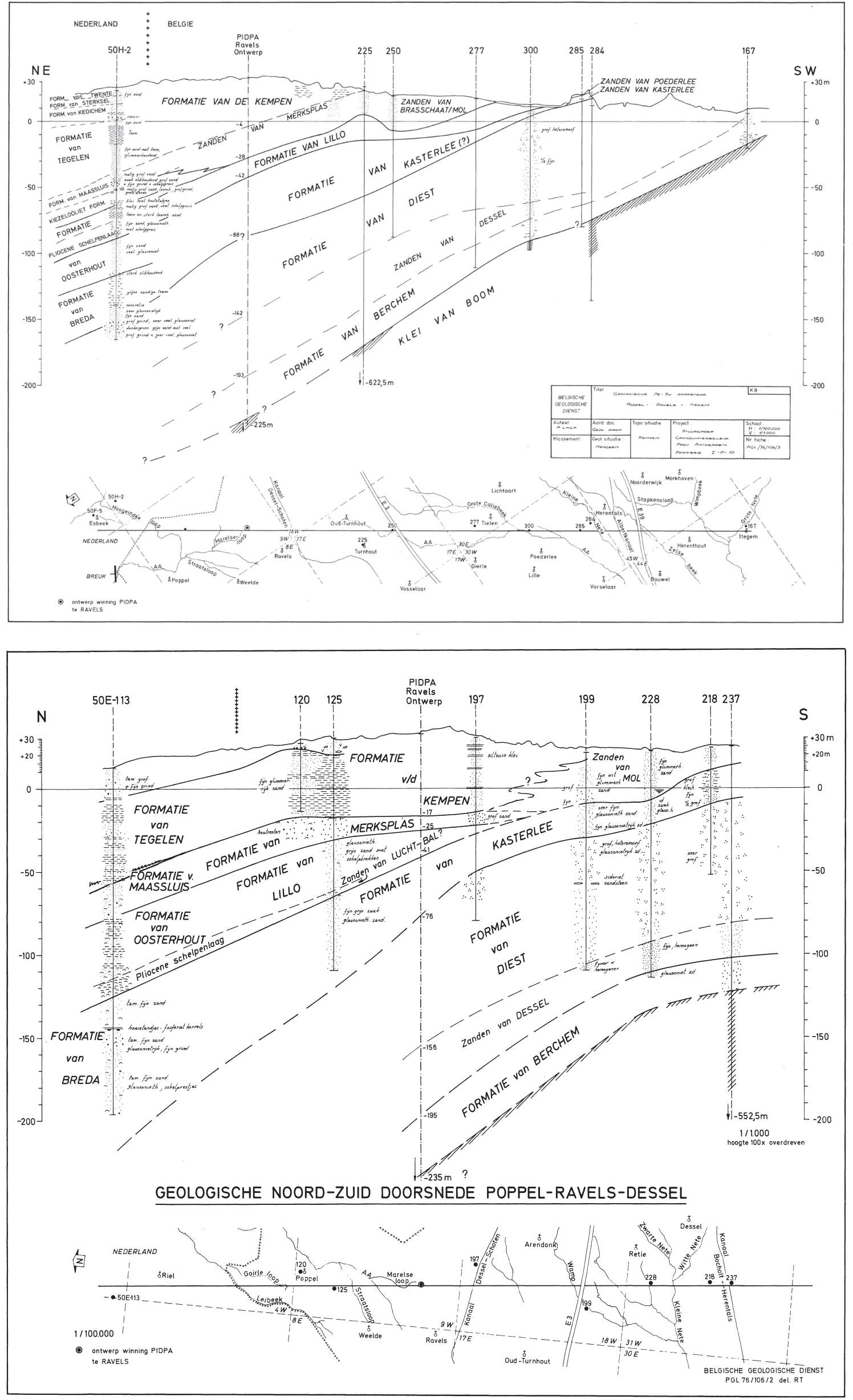

Figure 7a and 7b. Neogene profiles in the northern Campine (Laga, 1976, Archives of the Geological Survey of Belgium): PGL/76/106/3 (PoppelRavels-Turnhout) (Fig. 7a) and PGL 76/106/2 (Poppel-Ravels-Dessel) (Fig. 7b). The location of these profiles is indicated on Fig. 1 as 'Profile Fig 7a' and 'Profile Fig 7b'. These profiles crossing the border with the Netherlands illustrate the interpretation by the Geological Survey of the geometrical relationship between the Poederlee, Mol, Kasterlee, Diest, Breda Formations and some Pliocene units. 
Formation complicating the stratigraphic interpretation further eastwards. Besides, the Kasterlee Formation type section in the hill at Kasterlee is described as consisting entirely of fine sand while immediately to the east this type section is geometrically replaced by a lower 'clayey Kasterlee' unit and in part by an overlying fine sandy part labelled 'lower Mol' or 'Kasterleesensu-Gulinck' unit. Regarding the 'clayey Kasterlee' unit, CPT measurements and analysis have confirmed its equivalence with the lower part of the Kasterlee Formation type section (Fig. 3). Regarding the upper part in this type section at the N19a section in Kasterlee village, dark glauconite grains give this greyish sand a speckled aspect which is lacking in the 'lower Mol' or 'Kasterlee-sensu-Gulinck' unit in the ON-borehole series. Still both are for a large part occurring geometrically lateral from each other. Gulinck (1963) had realized the problem that in the Mol area the 'Kasterlee Sand' had lost its glauconite content but still decided to consider this greyish, pale-coloured fine sand that was colouring the drilling mud into green as Kasterlee Formation.

The main reason in the present study to label the sediments at a very short distance and geometrically lateral from the type Kasterlee Formation as 'lower Mol' unit is the absence of visible glauconite pellets and the pale grey colour which is in obvious contrast with the underlying greenish 'clayey Kasterlee' unit. There is no doubt that in common lithostratigraphic borehole interpretations the boundary between the pale white sand and the underlying green glauconitic sand will be interpreted as a major stratigraphic boundary (Plate $1 F, G)$. This is all the more true as this boundary represents a major sharp change in GR signature in all logs in that area (level 1 in Figs 2 and 5). It is worth noting that at the time Gulinck was making his stratigraphic subdivision no geophysical well logs were available. Also the pale grey to white 'lower Mol' unit is generally hard to distinguish from the overlying genuine Mol Formation. In addition, the contact between the green 'clayey Kasterlee' unit and the overlying pale white 'lower Mol' unit is interpreted to be erosive in several cored boreholes and therefore this 'lower Mol' fine white sand could be seen as a new sedimentation phase that then logically also should be in erosive contact laterally with the upper part of the Kasterlee Formation in the Lichtaart-Kasterlee hill. CPT measurements between the hill site and the closest-by borehole do not allow to decide between on the one hand a simple lateral facies change, as interpreted implicitly by Gulinck, and therefore the label 'Kasterlee-sensu-Gulinck' unit, or on the other hand a significant erosive contact between the upper part of the type Kasterlee Formation and the 'lower Mol' unit. The Kasterlee Formation, fully developed in fine glauconitic sand facies in the area of Herentals, Turnhout and Olen was proven to be of the same late Miocene dinoflagellate biostratigraphical age as the 'clayey Kasterlee' and the 'lower Mol' units (see also Louwye \& De Schepper, 2010). The outliers at the top of the Heist-op-denBerg and Beerzel hills, already lithostratigraphically correlated with the Olen outcrop using a typical base gravel (Verhaegen et al., 2014), are further correlated with the 'clayey Kasterlee' unit in the Dessel area by CPT measurements. The clayey deposits at the base of the Kasterlee Formation seem to occur at the southern and eastern fringe of the deposit whilst more northwards only glauconitic sand was deposited; in south Limburg at Helchteren, Gulinck (borehole 062E 0261, Archives of the Geological Survey of Belgium, 1964) describes clay containing grey-green 'Kasterliaan' and Fobe (1995) has also described in a sand pit at Helchteren (TO-19950101B) (Fig. 1) Kasterlee Sand with 20$25 \%$ clay fraction suggesting an equivalence with the Kasterlee Formation at Heist-op-den-Berg. If the 'lower Mol' unit is indeed a lateral facies of the upper part of the type Kasterlee Formation, then the whole Kasterlee Formation changes facies laterally towards its depositional fringe (see also Verhaegen et al., 2020, this volume).

The 'clayey Kasterlee' fringe area extends from Heist-op-denBerg and Helchteren in the south towards the zone Retie-PostelLommel in the northeast. The common presence of several very pure clay layers of some cm thickness in the 'clayey Kasterlee' fringe deposits is interpreted as the deposition from suspension in a lagoon type coastal area protected behind a barrier; when the barrier was ineffective by breaching or overwash, sand could be supplied from the open sea. There are no sedimentary indications of tidal currents, let alone tidal incisions of the size found in the Diest Formation. Palynology suggests that in the Olen and Dessel area the whole Kasterlee Formation was deposited in a bay connected to the sea and with riverine input.

The few similarly pure grey clay layers in the 'lower Mol' or 'Kasterlee-sensu-Gulinck' suggest a similar lagoonal depositional environment, though sand influx was much more important here. In the type area of the Kasterlee Formation sand to the northwest of the clayey fringe zone, palynology indicates a shallow marine depositional environment. The well-sorted, fine sand without clay fraction, where bioturbation erased any stratification or internal erosion structures, is typical for a lower shoreface depositional setting (see also Gullentops \& Huyghebaert, 1999, p. 192) thus signalling the existence of coastal barriers in the formation. The original westward extension of the Kasterlee Formation is unknown due to erosion at the base of the Kattendijk Formation; however, a palaeogeographic configuration was proposed by Verhaegen et al. $(2014,2020)$.

Palynology confirms earlier interpretations by Van den Broeck (1882) and Halet (1935) that in general the coarser Diest Sand was deposited in a somewhat deeper marine environment than the Kasterlee Formation. However it is also obvious that the common occurrence of several $\mathrm{cm}$ thick pure clay layers observed in the top of the Diest Formation near Mol-Dessel has to represent the same depositional setting behind a barrier system as in the 'clayey Kasterlee' unit. Nevertheless both lagoonal settings are separated by a transgressive event between the Diest and Kasterlee Formations. This transgression is evidenced in the southwest by the presence of a gravel layer followed by reworked Diest sand underlying the sandy deposits and the sand-clay alternations of the area (Verhaegen et al., 2014) and in the ON-boreholes by the systematic occurrence of a thin layer of reworked Diest sand sometimes with a $\mathrm{mm}$ thin very coarse sand at its base underlying the 'clayey Kasterlee' unit (see also Adriaens, 2015).

A final discussion topic as conclusion of the present study needs to be how to include the present analysis into formal lithostratigraphic nomenclature: how to label the 'units' identified in the present analysis and define their hierarchic relationship with the existing official lithostratigraphy as described in the National Commission for Stratigraphy Belgium (2020).

The 'upper Mol' unit in this study is undoubtedly part of the formal Mol Formation. East of the Rauw Fault the identification of the Maat lignite and tentatively the Russendorp lignite (Fig. 5) allows to recognize the traditional lower finer grained Donk Member and the upper coarser grained Maatheide Member. West of the Rauw Fault only the Donk Member is present as the Maat lignite occurs near the surface. However, westwards the grain size evolves significantly towards finer size and becomes hard to distinguish from the underlying 'lower Mol' or 'Kasterleesensu-Gulinck' unit (Fig. 2). This occurs geometrically lateral from the top part of the type Kasterlee Formation and from part of the Poederlee Formation in the classical hill reference section at Kasterlee (Fig. 1). This lateral relationship can be considered as an erosive contact although interfingering might be possible as well.

The Kasterlee Formation should be subdivided in at least (see further) two members. On the one hand there is the classical glauconitic green fine-grained sand facies including the more grey-greenish but still glauconite speckled sand at the eastern end of the Lichtaart-Kasterlee hill and on the other hand the welldefined 'clayey Kasterlee' unit, recognized also at the Heist-opden-Berg and Beerzel hills where they had already been associated with the Kasterlee Formation in the Leopoldsburg-Mol-Lommel area by Gulinck (1963).

The properties of the 'lower Mol' or 'Kasterlee-sensuGulinck' unit leave two options. The first option is to include this unit as another member of the Mol Formation. The arguments for this option are its pale grey colour and the very low GR signal which is more related to the Mol Formation than to the underlying 'clayey Kasterlee' unit, the erosive contact with this underlying 'clayey Kasterlee' unit, and the undoubtedly more practically recognisable twofold subdivision 'pale grey and pale white sand overlying green clayey sand' in borehole descriptions especially in destructive boreholes. It is very probable that this has also led to the practice of labelling a lower part of the 
Mol Formation as 'Mol Inférieur' where it becomes different from the white sand above by a colour turning more grey and picking up some clay and glauconite when in fact dealing with the 'lower Mol' or 'Kasterlee-sensu-Gulinck' unit as defined in the present paper. It is recommended anyway to drop the very poorly defined and loosely applied labels of Mol Inférieur and Mol Supérieur as sometimes used in borehole descriptions in the Archives of the Geological Survey and to apply instead the clear definitions of the 'lower Mol' and 'upper Mol' units as outlined in the present paper. The second option is to continue the practice applied by the Geological Survey in the tradition of Gulinck and to include this 'lower Mol' or 'Kasterlee-sensu-Gulinck' into the Kasterlee Formation, as a third member with a new label. Besides the important argument of literature continuity in stratigraphic interpretation and nomenclature also other arguments can be invoked in support of this option: its finer grain size compared with the overlying Mol Formation (Figs 2 and 5) which is more resembling the sandy Kasterlee Formation in the type area, the green colour of the clay fraction and of the drilling mud in this unit and its geometrical lateral position with respect to the type Kasterlee Formation section. Choosing between the two options is hard to do and would at least need more information on a full cored section of the Kasterlee Formation underlying the LichtaartKasterlee hill accompanied with more sedimentological and mineralogical analyses and geophysical borehole logging. Both the 'lower Mol' or 'Kasterlee-sensu-Gulinck' and the 'clayey Kasterlee' units hold the DN10 dinocyst zone.

The unnamed unit between the 'lower Mol' or 'Kasterleesensu-Gulinck' unit and the 'clayey Kasterlee' unit, namely between the levels 1 and 2 in Figure 5, would be preferably labelled as a separate unit but more information is required to make suggestions already in this paper. Its colour is described as pale whitish grey in borehole Lommel (Russendorp) (Laga, 1981; Archives of the Geological Survey of Belgium 031E 0341) and as light grey (greenish) in RUS04/03 by Vos (2009, p. 66), similar in both cases to the overlying 'lower Mol' or 'Kasterlee-sensuGulinck' units and interpreted in the tradition of the Geological Survey as part of the Kasterlee Formation in borehole Postel2/ SCK13 by Vos $(2009$, p. 93). Anyway it needs to be labelled as a new member and added either to the Mol Formation or the Kasterlee Formation, depending on the option chosen for the 'lower Mol' or 'Kasterlee-sensu-Gulinck' unit as discussed above. The same issue turns up when deciding on where to place the lower part of the Waubach sand unit, laterally equivalent of the 'lower Mol' or 'Kasterlee-sensu-Gulinck' including or not the unnamed unit between levels 1 to 2, but with respect to colour linked to the Kieseloolite Formation to which the Mol Formation is in part equivalent. The problem to rank the bed $\mathrm{X}$ in eastern Limburg is analogous: on the one hand the pale grey-yellowish colour suggests a lithostratigraphic link with the overlying Kieseloolite Formation and differentiates it strongly from the underlying glauconitic sand of the Breda Formation which on the other hand is equivalent in eastern Limburg with part of the Diest Formation with which bed X shares a similar dinocyst biozone. It is obvious that without new data no progress can be expected in the discussion on the proposed correlations.

\section{Conclusions}

In the early days of stratigraphy in Belgium the 'Casterlien' stratigraphic unit was introduced and as was the practice in these days it was meant to represent a particular time slice or chronostratigraphic unit. Since the introduction of the analytical stratigraphy distinguishing between litho-, bio- and chronostratigraphy in the 1970s (Hedberg, 1976), most of the early defined stratigraphic units were recognised to be in reality lithostratigraphic units and hence they were renamed in a nomenclature hierarchy of groups, formations and members. The Casterlien became the Kasterlee Formation, implying a switch of emphasis in interpretation from time equivalence to lithological equivalence (Laga et al., 2001). However, by that time the modern stratigraphic frame of the Belgian Campine had already been established in the 1960s and early 1970 s mainly by Gulinck and collaborators at the Geological Survey of Belgium. This explains why Gulinck has classified the sediments east of the Kasterlee village that are geometrically equivalent to the type Kasterlee Sand west of the Kasterlee village as 'Zand van Kasterlee' or 'Kasterliaan' although he himself recognised that these sediments to the east were lithologically different compared to the type Kasterlee Sand (Gulinck, 1963). This problem of lithostratigraphic characterisation became apparent when a new series of cored boreholes crossing the Mol and Kasterlee Formations into the Diest Formation were studied. Geophysical and CPT logging, grain-size analysis and mineralogical analysis - all lithostratigraphic tools - allowed to establish criteria to distinguish and correlate the several lithostratigraphic units present: Diest Sand, the type glauconitic Kasterlee Sand, a 'clayey Kasterlee' unit, a 'lower Mol' or 'Kasterlee-sensuGulinck' unit which corresponds to what Gulinck classified as Kasterlee Sand east of Kasterlee village, and an 'upper Mol' unit which corresponds to the Mol Formation. Using the criteria accepted in the present study, the Diest Sand is deposited during dinoflagellate cyst zone DN9 and the 'clayey Kasterlee' unit, the type green glauconite Kasterlee Sand and at least the lower part of the 'lower Mol' or 'Kasterlee-sensu-Gulinck' unit are deposited during the biochron DN10. East of the Mol Rauw Fault it was further possible to identify the Maat lignite in the Mol Formation and to suggest geometrical correlations accompanied by lithological changes of the 'clayey Kasterlee' and the 'lower Mol' or 'Kasterlee-sensu-Gulinck' unit into the RVG faulted area in the east of Limburg. The establishment of the stratigraphic hierarchy between all units identified needs to distinguish chronological from lithological criteria.

\section{Acknowledgements}

ONDRAF/NIRAS is thanked for allowing the use of the cores of the ON-boreholes for this study and for facilitating the retrieval of samples at many occasions. Sibelco is thanked for providing data on the Mol Sand and sharing their particular expertise on the Mol-Lommel area. Marleen De Ceukelaire of the Geological Survey of Belgium and Katrien De Nil of the DOV Flemish Community are sincerely thanked for retrieving data of boreholes at many occasions. Sincere thanks to Johan Matthijs for discussing earlier versions of this paper. Armin Menkovic and Bart Rogiers are thanked for their constructive reviews.

\section{References}

Adriaens, R., 2015. Neogene and Quaternary clay minerals in the southern North Sea. Unpublished Ph.D. Thesis, KU Leuven, Leuven, 272 p. https://limo.libis.be/primo-explore/fulldisplay?docid=LIRIAS19305 $87 \&$ context=L\&vid=Lirias\&search_scope=Lirias\&tab=default tab\&lang=en_US\&fromSitemap=1, accessed 15/03/2020.

Adriaens, R., Vandenberghe, N. \& Elsen, J., 2014. Natural clay-sized glauconite in the Neogene deposits in the Campine Basin (Belgium). Clays and Clay Minerals, 62, 35-52. https://doi.org/10.1346/ ccmn.2014.0620104

Adriaens, R. \& Vandenberghe, N., 2020. Quantitative clay mineralogy as a tool for lithostratigraphy of Neogene Formations in Belgium: a reconnaissance study. Geologica Belgica, 23/3-4, this volume. https://doi.org/10.20341/gb.2020.018

Archives of the Geological Survey of Belgium, Brussels. Information at: GSB@naturalsciences.be.

Beerten, K., Wemaere, I., Gedeon, M., Labat, S., Rogiers, B., Mallants, D. \& Salah, S., 2010. Geological, hydrogeological and hydrological data for the Dessel disposal site. Project near surface disposal of category A waste at Dessel. NIROND-TR 2009-05E Version 1. ONDRAFNIRAS, Brussels, 259 p.

Beerten, K., Vandersmissen, N., Deforce, K. \& Vandenberghe, N., 2014. Late Quaternary (15 ka to present) development of a sandy landscape in the Mol area, Campine region, north-east Belgium. Journal of Quaternary Science 29, 433-444. https://doi.org/10.1002/jqs.2713

Buffel, P., Claes, S. \& Gullentops, F., 2001a. Toelichtingen bij de geologische kaart van België, Vlaams Gewest: kaartblad 26, Rekem [1/50 000]. Belgische Geologische Dienst en Ministerie van de Vlaamse Gemeenschap, Afdeling Natuurlijke Rijkdommen en Energie, Brussel, 56 p.

Buffel, P., Vandenberghe, N., Goolaerts, S. \& Laga, P., 2001b. The Pliocene sediments in 4 boreholes in the Turnhout area (NorthBelgium): the relationship with the Lillo and Mol Formations. Aardkundige Mededelingen, 11, 1-8. 
Deckers, J., Vernes, R., Dabekaussen, W., Den Dulk, M., Doornenbal, H., Dusar, M., Hummelman, J., Matthijs, J., Menkovic, A., Reindersma, R., Walstra, J., Westerhoff, W. \& Witmans, N., 2014. Geologisch en hydrogeologisch 3D model van het Cenozoïcum van de Roerdalslenk in Zuidoost-Nederland en Vlaanderen (H3O - Roerdalslenk). Studie uitgevoerd in opdracht van: Afdeling Land en Bodembescherming, Ondergrond, Natuurlijke Rijkdommen van de Vlaamse Overheid; Afdeling Operationeel Waterbeheer van de Vlaamse Milieumaatschappij; Nederlandse Provincie Limburg; Nederlandse Provincie Noord-Brabant; TNO, Geologische Dienst Nederland; VITO/Energyville; in samenwerking met de Belgische Geologische Dienst. 2014/ETE/R/1; TNO 2014 R10799, 205 p.

Deckers J., De Koninck R., Bos S., Broothaers M., Dirix K., Hambsch L., Lagrou, D., Lanckacker T., Matthijs, J., Rombaut B., Van Baelen K. \& Van Haren T., 2019. Geologisch (G3Dv3) en hydrogeologisch (H3D) 3D-lagenmodel van Vlaanderen. Studie uitgevoerd in opdracht van het Vlaams Planbureau voor Omgeving, departement Omgeving en de Vlaamse Milieumaatschappij. VITO-rapport 2018/ RMA/R/1569, 286 p.

de Heinzelin, J., 1963. Colline de Lichtaart-Kasterlee. Compte-rendu des excursions. In Symposium sur la stratigraphie du Néogène nordique, Gand, 1961. Société belge de Géologie, de Paléontologie et d'Hydrologie, Mémoires in- $8^{\circ}, 6,216-217$.

de Mulder, F.J., Geluk, M.C., Ritsema, I.L., Westerhoff, W. \& Wong, T., (eds), 2003. De ondergrond van Nederland. Wolters Noordhoff, Groningen/Houten, 379 p.

De Nil, K., De Ceukelaire, M. \& Van Damme M., 2020. A reference dataset for the Neogene lithostratigraphy in Flanders, Belgium. Geologica Belgica, 23/3-4, this volume. https://doi.org/10.20341/ gb. 2020.021

de Verteuil, L. \& Norris, G., 1996. Miocene dinoflagellate stratigraphy and systematics of Maryland and Virginia. Micropaleontology, Supplement 42, 1-172. https://doi.org/10.2307/1485926

DOV, 2020. Databank Ondergrond Vlaanderen [Flanders Soil and Subsurface Database]. https://www.dov.vlaanderen.be, accessed $15 / 03 / 2020$.

Dumont, A., 1882. Mémoires sur les terrains crétacé et tertiaires préparés par feu A. Dumont pour servir à la description de la carte géologique de Belgique, 2 éd. par Mourlon, M. IV Terrains tertiaires, partie 3, $1-702$.

Dybkjaer, K. \& Piasecki, S., 2010. Neogene dinocyst zonation for the eastern North Sea Basin, Denmark. Review of Palaeobotany and Palynology, 161, 1-29. https://doi.org/10.1016/j.revpalbo.2010.02.005

Fobe, B., 1995. Lithologie en lithostratigrafie van de Formatie van Kasterlee (Plioceen van de Kempen). Natuurwetenschappelijk Tijdschrift, 75, 35-45.

Geets, S., 1962. Stratigrafische positie van het Poederliaan in de Antwerpse Kempen. Natuurwetenschappelijk Tijdschrift, 44, 143152.

Gulinck, M., 1960. Un gisement de kiezeloolithes à Lichtaart (Campine). Comparaison avec le cailloutis à kiezeloolithes des collines flamandes. Bulletin de la Société belge de Géologie, de Paléontologie et d'Hydrologie, 69, 191-210.

Gulinck, M., 1963. Essai d'une Carte géologique de la Campine. Etat de nos connaissances sur la nature des terrains néogènes recoupés par sondages. In Symposium sur la stratigraphie du Néogène nordique, Gand, 1961. Société belge de Géologie, de Paléontologie et d'Hydrologie, Mémoires in- ${ }^{\circ}$, 6, 30-39.

Gulinck, M. \& Laga, P., 1975. Boring SCK te Mol 31W-237. Geologische beschrijving door de Belgische Geologische Dienst. Archieven Belgische Geologische Dienst. http://gisel.naturalsciences.be/data/ text/031W/031W0237.txt, accessed 15/03/2020.

Gulinck, M., Geets, S. \& Van Voorthuyzen, J.H., 1963. Note sur les sondages du centre Nucléaire à Mol. Bulletin de la Société belge de Géologie, de Paléontologie et d'Hydrologie, 72, 283-394.

Gullentops, F., 1963. Etude de divers faciès quaternaires et tertiaires dans le Nord et 1'Est de la Belgique. Excursion O-P, 6e Congrès International de Sédimentologie 1963, Belgique et Pays-Bas, 20 p.

Gullentops, F. \& Huyghebaert, L., 1999. A profile through the Pliocene of Northern Kempen, Belgium. Aardkundige Mededelingen, 9, 191202.

Gullentops, F. \& Vandenberghe, N., 1995a. Geologische kaart van België, Vlaams Gewest: Mol, kaartblad 17. 1/50 000. Belgische Geologische Dienst en Afdeling Natuurlijke Rijkdommen en Energie, Brussel.

Gullentops, F. \& Vandenberghe, N., 1995b. Toelichtingen bij de geologische kaart van België, Vlaams Gewest: kaartblad 17, Mol [1/50 000]. Belgische Geologische Dienst en Ministerie van de Vlaamse Gemeenschap, Afdeling Natuurlijke Rijkdommen en Energie, Brussel, 65 p.
Halet, F., 1935. À propos des formations dites casterliennes des environs d'Herentals en Campine. Bulletin de la Société belge de Géologie, de Paléontologie et d'Hydrologie, 45, 290-297.

Hedberg, H.D. (ed.), 1976. International Stratigraphic Guide: a guide to stratigraphic classification, terminology, and procedure. John Wiley, New-York, 200 p.

Houthuys, R. \& Matthijs, J., 2020. Reinterpretation and update of the Neogene lithostratigraphy and structure of the "Bree Uplift", NE Belgium. Geologica Belgica, 23/3-4, this volume. https://doi. org/10.20341/gb.2020.020

Houthuys, R., Adriaens, R., Goolaerts, S., Laga, P., Louwye, S., Matthijs, J., Vandenberghe, N., Verhaegen, J., 2020. The Diest Formation: review of insights from the last decades. Geologica Belgica, 23/3-4, this volume. https://doi.org/10.20341/gb.2020.012

Jacobs, P., Polfliet, T., De Ceukelaire, M. \& Moerkerke, G., 2010. Toelichtingen bij de Geologische Kaart van België, Vlaams Gewest: kaartblad 15, Antwerpen [1/50 000]. Belgische Geologische Dienst en Ministerie van de Vlaamse Gemeenschap Afdeling Natuurlijke Rijkdommen en Energie, Brussel, 60 p.

Köthe, A., 2012. A revised Cenozoic dinoflagellate cyst and calcareous nannoplankton zonation for the German sector of the southeastern North Sea Basin. Newsletters on Stratigraphy, 45/3, 189-220. https:// doi.org/10.1127/0078-0421/2012/0021

Laga, P., 1976. Geologische Doorsneden. Archieven Belgische Geologische Dienst. http://collections.naturalsciences.be/sshgeology/geology/profiles-neogeen2020, accessed 15/03/2020.

Laga, P., 1981. Borehole description Lommel - Russendorp. Archives of the Geological Survey of Belgium. http://gisel.naturalsciences.be/ data/text/031E/031E0341, accessed 17/05/2020.

Laga, P. \& Louwye, S., 2006. Disused Neogene and Quaternary regional stages from Belgium: Bolderian, Houthalenian, Antwerpian, Diestian, Deurnian, Kasterlian, Kattendijkian, Scladisian, Poederlian, Merksemian and Flandrian. Geologica Belgica, 9/1-2, 215-224.

Laga, P. \& Notebaert, K., 1981. Description of the borehole Weelde - GSB 008E0133. Archieven Belgische Geologische Dienst. http://gisel. naturalsciences.be/data/text/008E/008E0133.TXT, accessed 15/03/2020.

Laga, P., Louwye, S. \& Geets, S., 2001. Paleogene and Neogene lithostratigraphic units (Belgium). In Bultynck, P. \& Dejonghe, L., (eds), Guide to a revised lithostratigraphic scale of Belgium. Geologica Belgica, 4/1-2, 135-152. https://doi.org/10.20341/ gb.2014.050

Louwye, S. \& De Schepper, S., 2010. The Miocene-Pliocene hiatus in the southern North Sea Basin (northern Belgium) revealed by dinoflagellate cysts. Geological Magazine, 147/5, 760-776. https:// doi.org/10.1017/S0016756810000191

Louwye, S. \& Laga, P., 2008. Dinoflagellate cyst stratigraphy and palaeoenvironment of the marginal marine Middle and Upper Miocene of the eastern Campine area, northern Belgium (southern North Sea basin). Geological Journal, 43, 75-94. https://doi. org/10.1002/gj.1103

Louwye, S., De Schepper, S., Laga, P. \& Vandenberghe, N., 2007. The Upper Miocene of the southern North Sea Basin (northern Belgium): a palaeoenvironmental and stratigraphical reconstruction using dinoflagellate cysts. Geological Magazine, 144, 33-52. https://doi. org/10.1017/S0016756806002627

Louwye, S. \& Vandenberghe, N., 2020a. A reappraisal of the dinoflagellate cyst biostratigraphy of the upper Miocene in the Maaseik well 49W0220. Geologica Belgica, 23/3-4, this volume. https://doi. org/10.20341/gb.2020.013

Louwye, S., Adriaens, R., Deckers, J., Verhaegen, J. \& Vandenberghe, N., $2020 \mathrm{~b}$. A review of the lower and middle Miocene in northern Belgium. Geologica Belgica, 23/3-4, this volume. https://doi. org/10.20341/gb.2020.010

Louwye, S., Adriaens, R., Deckers, J., De Schepper, S., Laga, P., Verhaegen, J. \& Vandenberghe, N., 2020c. A review of the Pliocene in northern Belgium. Geologica Belgica, 23/3-4, this volume. https:// doi.org/10.20341/gb.2020.016

National Commission for Stratigraphy Belgium, 2020. https://ncs. naturalsciences.be, accessed 15/03/2020.

Robertson, P.K., 2010. Estimating in-situ state parameter and friction angle in sandy soils from CPT. In Robertson, P.K. \& Mayne, P.W. (eds), $2^{\text {nd }}$ International Symposium on Cone Penetration Testing: CPT'10, Huntington Beach, CA, May 2010: conference proceedings, 8 p.

Rogiers, B, Mallants, D, Batelaan, O, Gedeon, M, Huysmans, M, Dassargues, A., 2012. The usefulness of CPTs for deterministic spatially heterogeneous, large-scale aquitard parameterisation. In Oswald, S.E., Kolditz, O., Attinger, S. (eds), Models - Repositories of Knowledge. Proceedings ModelCare 2011, Leipzig, Germany, 18-22 September 2011. IAHS Publication, 355, 41-47. 
Rogiers, B., Winters, P., Huysmans, M., Mallants, D., Batelaan, O. \& Dassargues, A., 2014a. High-resolution saturated hydraulic conductivity logging of borehole cores using air permeability measurements. Hydrogeology Journal, 22/6, 1345-1358. https://doi. org/10.1007/s10040-014-1144-y

Rogiers, B., Vienken, T., Gedeon, M., Batelaan, O., Mallants, D., Huysmans, M. \& Dassargues, A., 2014b. Multi-scale aquifer characterization and groundwater flow model parameterization using direct push technologies. Environmental Earth Sciences, 72, 13031324. https://doi.org/10.1007/s12665-014-3416-1

Schäfer, A. \& Utescher, T., 2014. Origin, sediment fill, and sequence stratigraphy of the Cenozoic Lower Rhine Basin (Germany) interpreted from well logs. German Journal Geoscience, 165, 287314. https://doi.org/10.1127/1860-1804/2014/0062

Schäfer, A., Utescher, T., Klett, M. \& Valdivia-Manchego, M., 2005. The Cenozoic Lower Rhine Basin - rifting, sedimentation, and cyclic stratigraphy. International Journal of Earth Science, 94/4, 621-639. https://doi.org/10.1007/s00531-005-0499-7

Schiltz, M., 2011. Kasterlee. Problematiek relatie Formaties van MolPoederlee-Kasterlee. Verslag $n^{\circ}$ 20111123. Unpublished report. Samsuffit Geoservices, 15 p.

Schiltz, M., 2020. On the use of CPT's in stratigraphy; recent observations and some illustrative cases. Geologica Belgica, 23/3-4, this volume. https://doi.org/10.20341/gb.2020.019

Schiltz, M., Vandenberghe, N. \& Gullentops, F., 1993a. Toelichtingen bij de geologische kaart van België, Vlaams Gewest: kaartblad 24, Aarschot [1/50 000]. Belgische Geologische Dienst en Ministerie van Vlaamse Gemeenschap, Afdeling Natuurlijke Rijkdommen en Energie, Brussel, 33 p.

Schiltz, M., Vandenberghe, N., Gullentops, F., 1993b. Toelichtingen bij de geologische kaart van België, Vlaams Gewest: kaartblad 16 Lier [1/50 000]. Belgische Geologische Dienst en Ministerie van de Vlaamse Gemeenschap, Afdeling Natuurlijke Rijkdommen en Energie, Brussel, 38 p.

Tavernier, R., 1954. Le Néogène. In Fourmarier, P. (ed.), Prodrome d'une description géologique de la Belgique, Volume hommage à Paul Fourmarier. Société géologique de Belgique, Liège, 533-554.

Tavernier, R. \& de Heinzelin, J., 1963. Introduction au Néogène de la Belgique. In Symposium sur la stratigraphie du Néogène nordique, Gand, 1961. Société belge de Géologie, de Paléontologie et d'Hydrologie, Mémoires in- $8^{\circ}, 6,7-28$, avec Essai d'une carte d'ensemble des formations néogènes de la Belgique et des régions voisines.

Utescher, T., Ashraf, A.R., Dreist, A., Dybkjaer, K., Mosbrugger, V., Pross, J. \& Wilde, V., 2012. Variability of Neogene continental climates in Northwest Europe - A detailed study based on microfloras. Turkish Journal of Earth Sciences, 21, 289-314. https://doi. org/10.3906/yer-1005-3

Vandenberghe, N., Herman, J., Laga, P., Louwye, S., De Schepper, S., Vandenberghe, J., Bohncke, S. \& Konert, M., 2000. The stratigraphic position of a Pliocene tidal clay deposit at Grobbendonk (Antwerp province, Belgium). Geologica Belgica, 3/3-4, 405-417. https://doi org/10.20341/gb.2014.040

Vandenberghe, N., Van Simaeys, S., Steurbaut, E., Jagt, J.W.M. \& Felder, P.J., 2004. Stratigraphic architecture of the Upper Cretaceous and Cenozoic along the southern border of the North Sea Basin in Belgium. Netherlands Journal Geosciences, 83/3, 155-171. https:// doi.org/10.1017/s0016774600020229

Vandenberghe, N., Laga, P., Louwye, S., Vanhoorne, R., Marquet, R., De Meuter F., Wouters, K. \& Hagemann, H.W., 2005. Stratigraphic interpretation of the Neogene marine-continental record in the Maaseik well (49W0220) in the Roer valley Graben, NE Belgium. Memoirs of the Geological Survey of Belgium, 52, $39 \mathrm{p}$.

Vandenberghe, N., Harris, W.B., Wampler, J.M., Houthuys, R., Louwye, S., Adriaens, R., Vos, K., Lanckacker, T., Matthijs, J., Deckers, J., Verhaegen, J., Laga, P., Westerhoff, W. \& Munsterman, D., 2014. The implications of K-Ar glauconite dating of the Diest Formation on the paleogeography of the Upper Miocene in Belgium. Geologica Belgica, 17, 161-174.

Van den Broeck, E., 1882. Diestien, Casterlien et Scaldisien. Note sur les dépôts lagunaires pliocènes d'Heyst-op-den-Berg et de Beersel et sur leur synchronisme dans la région d'Anvers. Annales de la Société royale Malacologique de Belgique, 17, CIII-CVIII.

Verbeeck, K., Wouters, L., Vanneste, K., Camelbeeck, T., Vandenberghe, D., Beerten, K., Rogiers, B., Schiltz, M., Burow, C., Mees, F., De Grave, J. \& Vandenberghe, N., 2017. Episodic activity of a dormant fault in tectonically stable Europe: The Rauw fault (NE Belgium). Tectonophysics, 699, 146-163. https://doi.org/10.1016/j. tecto.2017.01.023
Verhaegen, J. 2020. Stratigraphic discriminatory potential of heavy mineral analysis for the Neogene sediments of Belgium. Geologica Belgica, 23, 3-4, this volume. https://doi.org/10.20341/gb.2020.003

Verhaegen, J., Frederickx, L. \& Schiltz, M., 2020. New insights into the stratigraphy and paleogeography of the Messinian Kasterlee Formation from the analysis of a temporary outcrop. Geologica Belgica, 23/3-4, this volume. https://doi.org/10.20341/gb.2020.015

Verhaegen, J., Adriaens, R., Louwye, S., Vandenberghe, N. \& Vos, K. 2014. Sediment-petrological study supporting the presence of the Kasterlee Formation in the Heist-op-den-Berg and Beerzel hills, southern Antwerp Campine, Belgium. Geologica Belgica, 17, 323332.

Vernes, R.W., Deckers, J., Bakker, M.A.J., Bogemans, F., De Ceukelaire, M., Doornenbal, J.C., den Dulk, M., Dusar, M., Van Haren, T.F.M., Heyvaert, V.M.A., Kiden, P., Kruisselbrink, A.F., Lanckacker, T. Menkovic, A., Meyvis, B., Munsterman, D.K., Reindersma, R., Rombaut, B., ten Veen, J.H., van de Ven, T.J.M., Walstra, J. \& Witmans, N., 2018. Geologisch en hydrogeologisch 3D model van het Cenozoïcum van de Belgisch-Nederlandse grensstreek van Midden-Brabant / De Kempen (H3O - De Kempen). TNO-rapport TNO 2017 R11261 - VITO 2017/RMA/R/1348. 109 p.

Vos, K., 2009. De Neogene en Quartaire geologie van Mol en Lommel in het grensgebied België-Nederland, ten noorden van het kanaal BocholtHerentals. Unpublished Master Science Geology Thesis, KU Leuven, Leuven, 136 p. https://eu00.userservices.exlibrisgroup.com/view/ delivery/32KUL_KUL/12444874980001488, accessed 15/03/2020.

Welkenhuysen, K. \& De Ceukelaire, M., 2009. Tertiair lithostratigrafische interpretatie op basis van geofysische boorgatmetingen van de boringen van meetnet 1 VMM-afdeling water uitgevoerd in 20052006. Geological Survey of Belgium, Professional Paper, 2009/2, 306, $77 \mathrm{p}$.

Wouters, L. \& Schiltz, M., 2012. Overview of the field investigations in and around the nuclear site of Mol-Dessel. Project near surface disposal of category A waste at Dessel. ONDRAF/NIRAS and Samsuffit Geoservices Report, 139 p.

Manuscript received 03.12.2019, accepted in revised form 23.03.2020, available online 22.05.2020. 
Plate 1. Photographs A and B show their label in the lower corner of each photograph; the photographs C, D, E, F, I point to the corresponding photograph by small black arrows and all cores in photographs $\mathrm{E}$ to I are figured in the correct vertical geometric position and with relative measuring scale in $\mathrm{cm}$, photograph I consists of two cores, core $\mathrm{G}$ is represented twice under different preservation conditions, core $\mathrm{H}$ is represented together with two magnifications.

A. The Lichtaart sand pit Hoge Berg (nr 27 in Fig. 1). At about $15 \mathrm{~cm}$ from the top of the photograph occurs the contact between the Kasterlee Formation below and the Poederlee Formation above (red dashed line). The level contains the small Hukkelberg gravel quartz pebbles, not visible at the scale of the photograph, and several fragments of white slightly silica cemented sand similar to the Mol Formation sand. The sand in the Kasterlee Formation is fine and homogeneous due to bioturbation; note greenish colour of the sand at the left and pale grey sand with liesegang rings at the right (photo 2018, R.H.).

B. The temporary N19g outcrop near the eastern end of the Lichtaart-Kasterlee hill (nr 2 in Fig. 1). In the middle of the photograph occurs the up to 20 cm thick Hukkelberg basal level separating the Poederlee Sand above from the Kasterlee Sand below (red dashed line). Its composition is variable with dispersed small typical flat quartz pebbles, some pure clay lumps and iron cemented sandstone fragments. The Poederlee Sand is fine grained, bioturbated and shows a large scale inclined stratification. The Kasterlee Sand below is fine grained almost without stratification, bioturbated and with a variable glauconite content; its colour is pale grey but strong secondary oxidation is visible at the right side of the photograph (photo 2012, M.S.).

C. Section in the Kasterlee Formation at Heist-op-den-Berg during construction works (Verhaegen et al., 2020, this volume); the interval shown is about $3 \mathrm{~m}$ high and shows a lower part with the homogeneous, bioturbated marine glauconitic Beerzel member, overlain by the banded-clay interval of the Heist-op-den-Berg member (red dashed line at the contact). Both members are part of the Kasterlee Formation (Verhaegen et al., 2014) (photo 2019, J.V.).

D. General view of the Mol Formation in the Sibelco sand pit at Blauwe Kei (near nr 32 on Fig. 1). The lignite layer in the middle of the photo is the Russendorp lignite level (red arrows). In this sand pit the Maat lignite occurs between 18.7 and $19.1 \mathrm{~m}$ depth (info K.V.). Note to the right of the disturbed zone in the middle of the photograph marked large scale inclined stratification in the Mol Formation (photo 2010, SCK/CEN Mol).

E. Core with the 'lower Mol' or 'Kasterlee-sensu-Gulinck' unit interval 26.40-26.82 $\mathrm{m}$ in borehole ON-Dessel-4 (nr 8 in Fig. 1). Note the occurrence of relatively thick pure grey clay layers in the otherwise pale grey-greenish homogeneous sand (photo SCK/CEN Mol).

F. Core of the interval 12-13 m in borehole ON-Kasterlee-1 (nr 3 in Fig. 1). Note at about $12.75 \mathrm{~m}$ depth (red dashed line) the marked colour contrast between pale sand of the 'lower Mol' or 'Kasterlee-sensu-Gulinck' unit above and the darker green colour of the 'clayey Kasterlee' unit below. Note also in the upper $75 \mathrm{~cm}$ of the core the marked laminated nature of the base of the 'lower Mol' or 'Kasterlee-sensu-Gulinck' unit (photo SCK/CEN Mol).

G. On both sides of the measuring stick, the same short core in the ON-Retie-1 borehole (nr 6 in Fig. 1) photographed with a time interval of several years; both photographs show the contact (red dashed line at $24.65 \mathrm{~m}$ ) between the pale coloured 'lower Mol' or 'Kasterlee-sensu-Gulinck' unit in the upper part and the dark green coloured 'clayey Kasterlee' unit below but note the slight difference in colour shade between the two photographs (photos SCK/CEN Mol and R.H.)

H. The one metre long core in the middle is the top of the 'clayey Kasterlee' unit at 29.82-30.82 m in the ON-Dessel-4 borehole (nr 8 in Fig. 1); on both sides a part of the core is shown in detail. Note the occurrence of pale grey pure clay layers alternating with darker green sand; the small irregularities inside and at the boundary of the clay layers are due to currents and bioturbation.

I. Two intervals in the 'clayey Kasterlee' unit; left core 25-26 m in borehole ON-Retie-1 (nr 6 in Fig. 1) and right core $19.15-20 \mathrm{~m}$ in borehole ON-Retie-2 (nr 4 in Fig. 1) showing the common occurrence of $\mathrm{cm}$ scale pale grey pure clay layers in the dark green sands. The pale grey upper $15 \mathrm{~cm}$ sand in the ON-Retie-2 borehole (right) is the base of the 'lower Mol' or 'Kasterlee-sensu-Gulinck' unit (red dashed line). The small bends at the rim of the cores are induced during coring. 


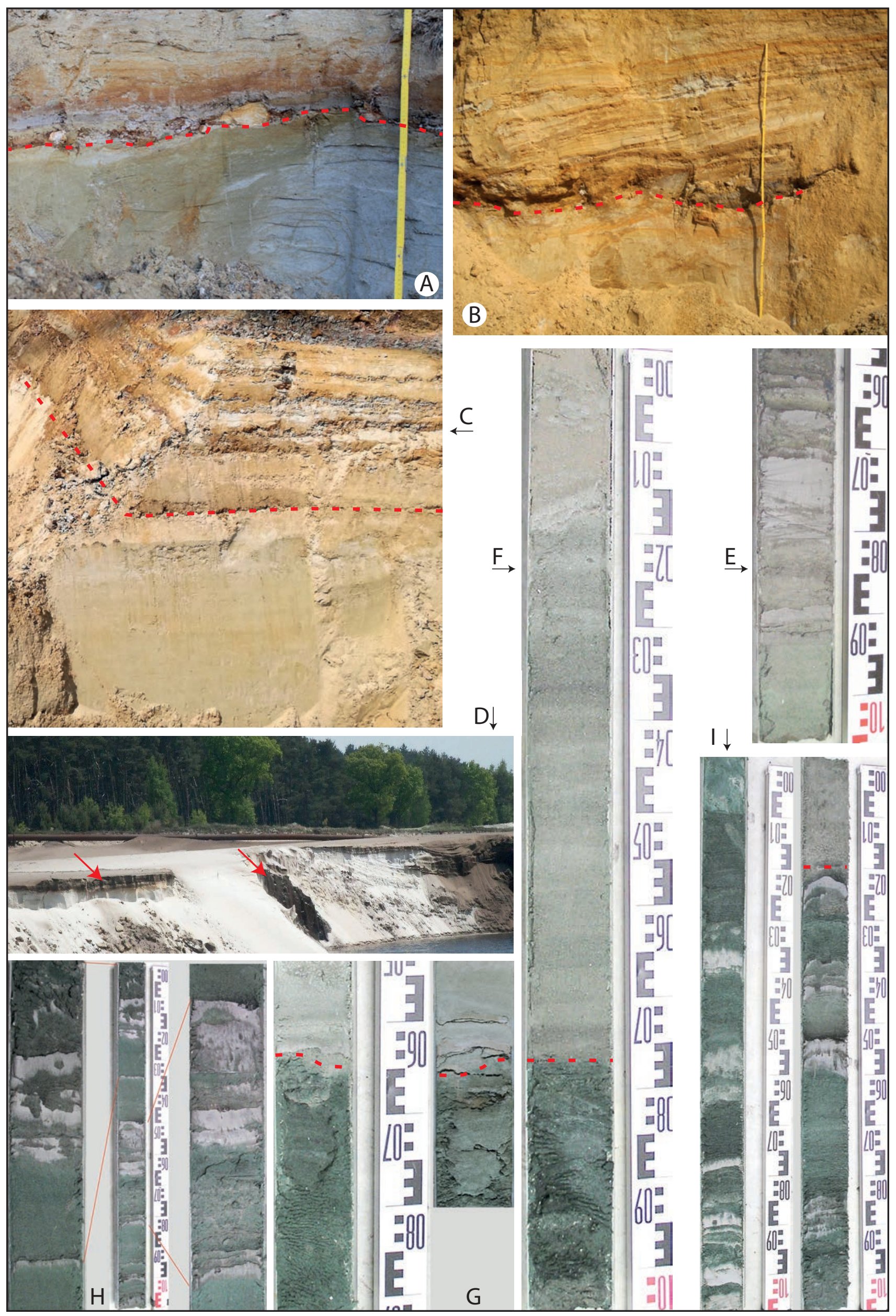

